Universidade de Brasília

Centro de Desenvolvimento Sustentável

A Construção do Sistema Brasileiro de Declaração Ambiental de Produto

Verônica Moreira Horner Hoe

Orientador: Professor Doutor Armando Caldeira Pires

Dissertação de Mestrado

Brasília, DF

09/2016 
Universidade de Brasília

Centro de Desenvolvimento Sustentável

\section{A Construção do Sistema Brasileiro de Declaração Ambiental de Produto}

Dissertação de mestrado submetida ao Centro de Desenvolvimento Sustentável da Universidade de Brasília, como parte dos requisitos necessários para a obtenção do Grau de Mestre em Desenvolvimento Sustentável

Aprovada por:

Professor Doutor Armando Caldeira Pires, (CDS/UnB) (Orientador)

Professor Doutor Maurício Amazonas, (CDS/UnB)

(Examinador Interno)

Professora Doutora Cristiane Mascarenhas S. Sampaio (INMETRO) (Examinador Externo)

Brasília, DF, 02 de setembro de 2016. 
HOE, Verônica Moreira Horner

A Construção do Sistema Brasileiro de Declaração Ambiental do Produto. 85p., (UnBCDS, Mestre, Desenvolvimento Sustentável, 2016).

Dissertação de Mestrado - Universidade de Brasília. Centro de Desenvolvimento Sustentável.

1. Declaração ambiental de produtos $\quad 2$. Desenvolvimento sustentável

3. rotulagem 4. Política pública

I. UnB-CDS

É concedida à Universidade de Brasília permissão para reproduzir cópias desta tese e emprestar ou vender tais cópias somente para propósitos acadêmicos e científicos. A autora reserva outros direitos de publicação e nenhuma parte desta tese de doutorado pode ser reproduzida sem a autorização por escrito da autora. 


\section{AGRADECIMENTOS}

Ao meu orientador, professor Armando, que desde o início me auxiliou nesta pesquisa.

Ao meu marido Fidel, pela paciência durante todo este processo e por todo apoio durante todos os momentos da minha vida.

Aos entrevistados que foram bastante solícitos e sem os quais este trabalho não seria possível. À Sra. Maria Aparecida Martinelli, ao Sr, Mário Cardoso, Sr. Keyvan Macedo e Sr. Antonio Maschietto, um agradecimento muito especial pelo pronto atendimento e toda colaboração.

Aos meus amigos que nas horas mais difíceis souberam como me distrair.

A todos os outros colegas que de alguma maneira estiveram envolvidos na construção desta dissertação.

Muito obrigada! 


\section{RESUMO}

A rotulagem ambiental tipo III tem sido adotada por diversos países no mundo, especialmente após as exigências dos países europeus. Tem-se observado o crescimento da rotulagem tipo III e da elaboração das regras de categoria de produtos em diferentes setores, inclusive em setores de produtos de consumo, como os cosméticos. O Brasil recentemente publicou seu Programa de Rotulagem tipo III-DAP, através de regulamento do Instituto Nacional de Metrologia, Qualidade e Tecnologia (INMETRO), que já era o órgão responsável pelo Programa Brasileiro de Avaliação do Ciclo de Vida. Este trabalho teve por objetivo identificar e analisar os instrumentos, desafios, limites e possibilidade para a implementação do programa proposto pelo INMETRO para rotulagem tipo III, a partir da avaliação de experiências internacionais. Utilizou-se como referência o setor de cosméticos e produtos de higiene pessoal. $\mathrm{O}$ que se concluiu é que o programa do INMETRO ainda é muito recente, mas segue alinhado com os programas dos demais países, e isto the permitirá um reconhecimento mútuo no futuro. O setor de cosméticos pode servir como modelo para a implementação de tal programa, tendo em vista que já possui algumas iniciativas em rotulagem ambiental atualmente.

Palavras-chave: 1. Declaração Ambiental de Produtos; 2. Desenvolvimento sustentável; 3. Rotulagem Ambiental; 4. Políticas Públicas 


\section{SUMÁRIO}

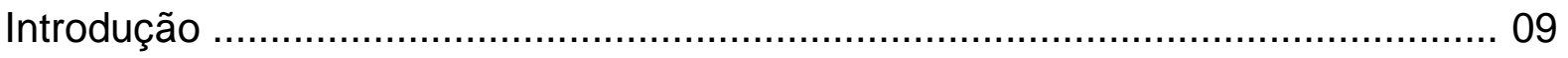

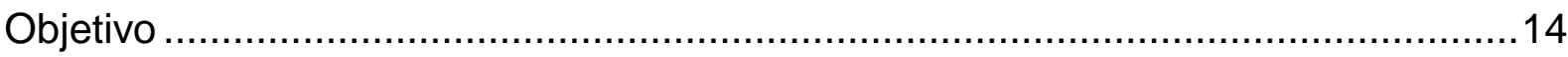

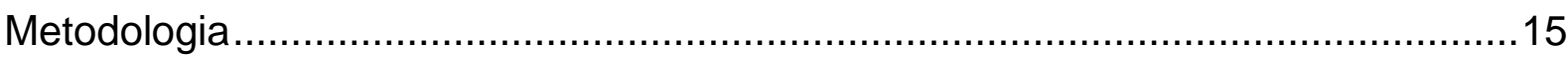

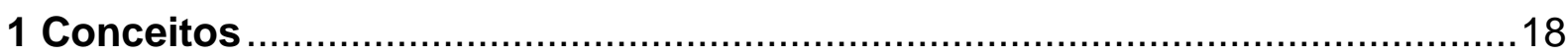

1.1 Avaliação do Ciclo de Vida e o Processo Produtivo ........................................... 18

1.2 Rotulagem Ambiental e Declaração Ambiental do Produto ………................... 20

20 estado da arte - os sistemas de declaração ambiental de produto no mundo e sua implementação a partir de políticas de incentivo ………………..........233

2.1 Os sistemas de Declarações Ambientais de Produto no Mundo ........................ 23 2.2 Políticas Públicas e Iniciativas no Mundo: Sintonia e Integração com a Declaração Ambiental de Produtos ................................................................................ 38

3 A Proposta do Sistema Brasileiro de Declaração Ambiental de Produto e rotulagem tipo III ........................................................................... 42

3.1 Histórico do sistema de Declaração Ambiental de Produto no Brasil ................. 42

3.2 Políticas Públicas e Iniciativas: sintonia e integração com a Declaração Ambiental

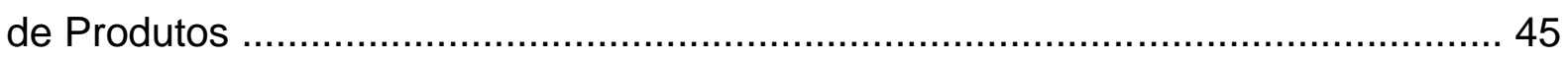

3.3 O sistema brasileiro de Declaração Ambiental de Produtos e os Sistemas no

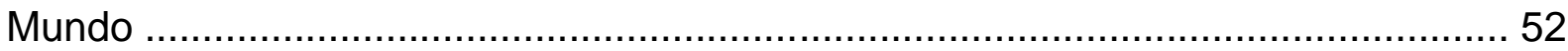

3.4 O sistema brasileiro de Declaração Ambiental de Produto ………..................... 54

4 Estudo de caso: a rotulagem ambiental no setor de produtos de higiene pessoal e cosméticos e a relação com o consumo sustentável .........................64

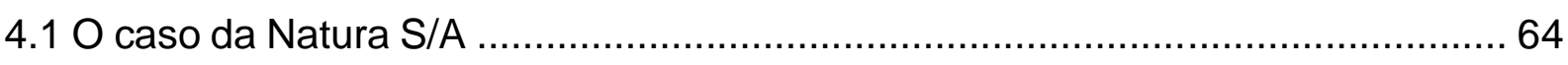

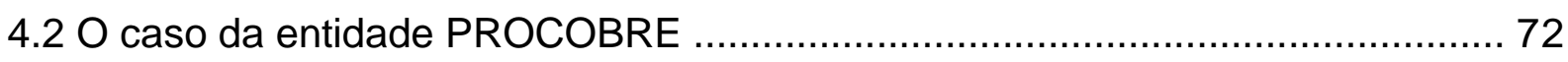

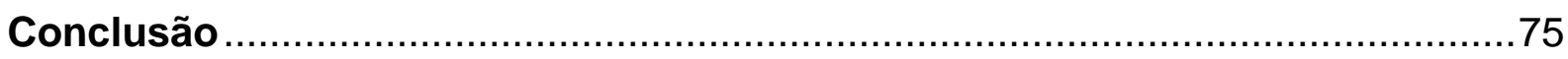

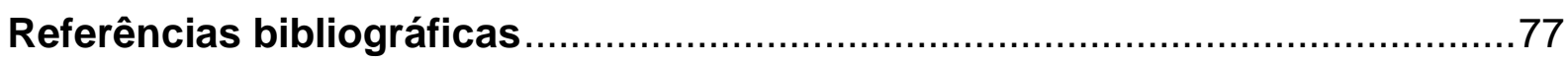

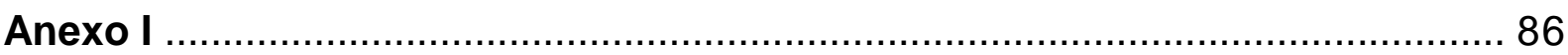




\section{LISTA DE FIGURAS}

Figura 1: Exemplo de selos usados na rotulagem tipo II. Fonte: Foto de autoria própria. Produto: desodorante aerossol. 21

Figura 2: Sistema de DAP ECOLEAF, Japão. Fonte: JEMAI, 2001. .30

Figura 3: Sistema DAP do Canadá. Fonte: CSA GROUP, [s.d.] 35

Figura 4: Estrutura da Comissão Europeia para Rotulagem Ambiental. Fonte: Autoria própria, com base em UNIÃO EUROPEIA (2010). .26

Figura 5: Sistema Nacional de Metrologia, Normalização e Qualidade Industrial (SINMETRO). Fonte: Autoria própria. .43

Figura 6: Sistema brasileiro de DAP. Fonte: Autoria própria. .55

Figura 7: Fluxograma das etapas de elaboração de Declaração Ambiental de Produto (DAP). Fonte: Autoria própria. .57

Figura 8: Análise SWOT do Programa DAP brasileiro. Fonte: Autoria própria.........59

Figura 9: Rótulo Ambiental da Natura, para dois óleos corporais. .66

Figura 10: Informações de Embalagem na tabela ambiental do produto óleo corporal Natura. .67

Figura 11: Informações de Formulação na tabela ambiental do produto óleo corporal da Natura. .68 


\section{LISTA DE QUADROS}

Tabela 1: Comparação entre os programas de DAP. .54 


\section{INTRODUÇÃO}

$\mathrm{Na}$ sociedade contemporânea o consumo tem definido a identidade e o estilo de vida do indivíduo, tornando-se sinônimo de felicidade e inclusão. Este estímulo ao consumo tem sido cada vez maior, inclusive com a adoção de políticas de estímulo ao consumo por parte do Estado (HOE, 2014).

O que se observa nos últimos anos é uma certa conscientização e mudança na forma de consumo de alguns indivíduos. Os mais jovens, por exemplo, têm adotado uma postura de consumo baseado em seus valores, estes relacionados, principalmente, à qualidade de vida, tornando a comunicação em massa e as pesquisas de marketing pouco efetivas na identificação de informações desejadas e essenciais às pessoas (AUSTRUMA, 2012).

Essa tendência de mudança no padrão de consumo, pode apontar para o caminho de um consumo mais consciente o que exigiria informações confiáveis de fácil acesso pelos consumidores. É neste sentido que a rotulagem ambiental tipo III pode contribuir.

O PNUMA ${ }^{1}$, define consumo sustentável como:

$\mathrm{O}$ uso de bens e serviços que atendam às necessidades básicas, proporcionando uma melhor qualidade de vida, enquanto minimizam o uso dos recursos naturais e materiais tóxicos, a geração de resíduos e a emissão de poluentes durante todo ciclo de vida do produto ou do serviço, de modo que não se coloque em risco as necessidades das futuras gerações (PNUMA, p.14, 2004).

Diversos estudos demonstram que muitos consumidores pagariam a mais por um produto se este se mostrar mais sustentável quando comparado a outros produtos da mesma categoria. Os rótulos ambientais e de sustentabilidade podem auxiliar os consumidores na decisão de sua escolha, fornecendo essas informações (CHEN et al., 2014).

Ao longo do tempo observa-se 0 aumento da preocupação dos consumidores com suas escolhas. Estudo realizado na França mostra que em 1993 apenas $36 \%$ da população preocupava-se com as questões ambientais;

\footnotetext{
1 PNUMA: Programa das Nações Unidas para o Meio Ambiente.
} 
em 2011, este número já era de 53\% (CECI-RENAUD \& KHAMSING, 2012). Em estudo realizado na Europa, em 2013, 81\% da população gostaria de encontrar informações ambientais nos rótulos dos produtos (EUROBAROMETER, 2013). De acordo com pesquisa realizada pela empresa Market Analisys ${ }^{2}$ (2014), no Brasil, $73 \%$ dos consumidores têm interesse em incluir em sua lista de consumo produtos verdes e $36 \%$ gostariam que os produtos tivessem uma certificação para atestar sua produção sustentável.

O consumo de produtos sustentáveis e produtos verdes dá às pessoas a sensação de estarem contribuindo com a melhoria do meio ambiente e por esta razão, cada vez mais consumidores buscam esse tipo de informação. Mas, ainda há muita desconfiança em torno das informações disponibilizadas.

Observando a mudança no comportamento do consumidor, muitas empresas de produtos de consumo têm adotado a disponibilização de informações ambientais nos seus rótulos, apesar da dificuldade da grande parte dos consumidores em entende-las.

O desafio das empresas, de governo e da população de modo geral, tem sido desenvolver uma economia que o planeta possa suportar indefinidamente. Políticas têm sido propostas, visando tornar os negócios e o consumo mais sustentáveis. As empresas precisam se adaptar às novas exigências. Se no passado as empresas precisavam apenas conhecer seus impactos, hoje buscase reduzi-lo na tentativa de alcançar impacto zero e, provavelmente, no futuro o objetivo será o impacto positivo (FINKBEINER, 2014).

A rotulagem ambiental é um mecanismo de comunicação com os consumidores de determinado produto, através da disponibilização de informações ambientais relevantes para o público, pré-determinadas por requisitos específicos (BARRETO et al., 2007; ENVIRONMENTAL PROTECTION AGENCY, 1998).

Atualmente, todos os países parte do $\mathrm{G}^{3}$ possuem, de alguma maneira, ações contínuas para informar aos consumidores de produtos e serviços 0 desempenho ambiental desses. Essas informações têm sido disseminadas, em muitos casos, a partir de programas de rotulagem ambiental, que observam o

\footnotetext{
2 Market Analisys: empresa privada de pesquisas com consumidor.

${ }^{3}$ G7: Grupo que reúne os sete países que primeiro de industrializaram no mundo. Formado por Estados Unidos, Canadá, Alemanha, França, Itália, Reino Unido e Japão.
} 
ciclo de vida de todo produto ou serviço, incluindo o processo (ENVIRONMENTAL PROTECTION AGENCY, 1998).

As rotulagens ambientais estão classificadas de acordo com a série de normas ISO 14020 (14021; 14024 e 14025). A rotulagem tipo I, normatizada pela ISO 14021 dispõe sobre os critérios para rotulagem certificada, incluindo requisitos para certificação por terceira parte. A rotulagem tipo II é auto declaratória e segue os requisitos previstos na ISO 14024. Já a rotulagem tipo III trata da declaração ambiental de produto (DAP) e deve ser elaborada conforme a Avaliação do Ciclo de Vida (ACV) do produto. A norma desta rotulagem é a ISO 14025 (BARRETO et al., 2007).

Parte integrante de diversas outras políticas de sustentabilidade e de mercado, a rotulagem ambiental tipo III, baseada na DAP, tem ganhado espaço, após as exigências europeias para a prestação deste tipo de informação aos consumidores.

A DAP é uma ferramenta de informação e também de levantamento das características ambientais de processos produtivos. Por ser baseada na ACV do produto ou serviço, a elaboração da DAP depende do levantamento de informações geradas por essa Avaliação. Por isto, a implementação da rotulagem tipo III depende de fatores como a existência de banco de dados de $A C V$, um programa bem definido, o tempo de existência e a institucionalização do programa. Esses são aspectos relevantes ao se analisar a produtividade e efetividade das DAP (HUNSAGER, et al, 2014).

Por se tratar de uma informação disponibilizada ao consumidor e verificada por terceira parte, a veracidade das informações torna-se ponto chave da rotulagem ambiental tipo III. Assim, este tipo de rotulagem tem sido bastante utilizada na integração com as políticas de produção e consumo sustentáveis dos diversos países.

Um indício de que o uso da rotulagem tipo III está crescendo advém do aumento de declarações ambientais de produtos em países que não se encontram na Europa ou na América do Norte, como observado por Minkov et al. (2015). Há um crescimento no número de DAP na Austrália, Japão e França, que possuem obrigatoriedade na adoção da rotulagem e podem ser considerados modelos a serem seguidos. Observa-se a estrutura montada pelos 
países para tal obrigatoriedade, como legislação adequada, base de dados nacional e regras setoriais específicas (SCHENCK, 2009).

Com a obrigatoriedade da rotulagem em muitos países, especialmente, nos países da comunidade europeia, observa-se o crescente número de programas de rotulagem tipo III pelo mundo. O Brasil, apesar de um pouco atrasado em relação aos demais países, não ficou de fora e elaborou seu programa.

Ainda recente, o Programa de Rotulagem tipo III-DAP brasileiro está sendo proposto pelo Instituto Nacional de Metrologia, Qualidade e Tecnologia (INMETRO), através de uma Portaria, o 100/2016. Voluntário, sua implementação pode ser realizada por qualquer setor industrial, dando a possibilidade de integrar este programa com outras políticas ambientais e de sustentabilidade já implementadas no país.

Diversos setores da indústria têm se preocupado em atender seus consumidores com informações ambientais, na busca de ganho de espaço no mercado. O setor de cosméticos é um deles. O consumidor desses produtos busca por produtos de qualidade e de baixo impacto para a saúde e para o meio ambiente. É um setor que tem crescido anualmente, em contradição aos demais setores da indústria, chegando, o mercado brasileiro, a responder por cerca de $10 \%$ do consumo mundial de cosméticos e produtos de higiene pessoal (ABIHPEC, 2015).

No que tange a rotulagem ambiental, existe, por exemplo, uma rotulagem na Bélgica voltada aos cosméticos orgânicos. Neste caso, o selo é concedido pela Associação do setor (International Natural and Organic Cosmetics Association A.I.S.B.L.), e a própria entidade verifica e certifica os produtos, classificados em 3 categorias: cosmético natural, cosmético com $70 \%$ de orgânico e cosmético com $95 \%$ de orgânicos. Outros selos como livres de testes em animais também são bastante utilizados em cosméticos (NATRUE, [s.d.]).

Este tipo de apelo em cosméticos torna-se importante para o consumidor que exige produtos diferenciados. Por esta razão, este trabalho analisou a rotulagem ambiental de produtos da empresa Natura S.A, que apesar de não ser do tipo III pode ser facilmente integrada no programa proposto pelo INMETRO. A empresa foi escolhida tendo em vista sua cultura voltada à sustentabilidade e às inciativas já implementadas para comunicação ambiental com seus 
consumidores, através de uma rotulagem ambiental baseada na Avaliação do Ciclo de Vida de seus produtos.

O objetivo deste trabalho foi identificar e analisar os instrumentos, desafios, limites e possibilidade para a implementação do programa proposto pelo INMETRO para rotulagem tipo III.

O que se observou é que a política brasileira está no caminho certo, alinhado com os demais países do mundo, porém, é preciso ainda integrar esta política com outras já implementadas, visando incentivar a adoção da DAP pelas empresas localizadas no Brasil. Também é preciso um amadurecimento do programa, ainda muito recente.

O trabalho está dividido da seguinte forma: no capítulo 1 encontram-se os conceitos importantes para o entendimento deste trabalho; o capítulo 2 traz os programas existentes no mundo; o capítulo 3 apresenta o sistema do brasileiro, avaliando os seus pontos fortes e fracos. O capítulo 4 é resultado de uma entrevista realizada com uma indústria do setor cosmético e uma entidade de classe, cujo setor já implementou a DAP, baseada em um sistema internacional. 


\section{OBJETIVO}

O objetivo geral deste trabalho de pesquisa é identificar e analisar os instrumentos, desafios, limites e possibilidades para a implementação da política de rotulagem ambiental, estabelecida pelo INMETRO, através do Programa Voluntário de Rotulagem Ambiental Tipo III-Declaração Ambiental de Produto (DAP). Para a análise da política proposta está sendo utilizado como referência o setor de produtos de higiene pessoal e cosméticos.

Esta pesquisa possui cinco objetivos específicos:

Caracterizar os sistemas internacionais de DAP;

Apresentar e caracterizar o sistema nacional de DAP, instituído pelo INMETRO (Portaria ํㅡ 100/2016);

> Identificar os principais componentes nos sistemas internacionais de DAP, que estimulam sua utilização;

Investigar e analisar iniciativas já praticadas no Brasil pelo setor de cosméticos, que promovem a declaração ambiental de produto e a rotulagem ambiental;

- Analisar como empresas nacionais podem utilizar a rotulagem ambiental tipo III e os estímulos necessários para adoção de tal iniciativa. 


\section{METODOLOGIA}

Para a realização deste trabalho foi realizada uma análise crítica, a fim de verificar o cenário internacional e as condições brasileiras necessárias para a implementação da DAP e rotulagem ambiental tipo III. Essa avaliação crítica ocorreu a partir da revisão bibliográfica sistemática, desde o ano 2000 até 2015, buscando-se o histórico de implementação da declaração ambiental de produtos (DAP) e rotulagem ambiental em âmbito internacional.

Utilizou-se nesta pesquisa, como palavras-chave: ciclo de vida, declaração ambiental de produto, rotulagem ambiental, consumo e produção sustentáveis, sustentabilidade e competição empresarial. As buscas foram realizadas em português, inglês e espanhol, para se atingir o maior número possível de informações.

Após análise da pesquisa bibliográfica, foram levantadas as possíveis políticas públicas de estímulo que podem ser implementadas. Para isto, avaliouse algumas políticas já existentes, e como estas poderiam ser alavancadas, e novas propostas conforme experiência internacional.

A política pública de DAP foi analisada utilizando-se a metodologia SWOT. A denominação SWOT é uma sigla em inglês advinda das palavras Strenghts (Forças), Weaknesses (Fraquezas), Opportunities (Oportunidades) e Threats (Ameaças) (MACERON FILHO, et al., 2014). Esta metodologia foi criada por dois professores de Harvard para ser utilizada na elaboração do planejamento estratégico, mas já é possível observar sua aplicação na análise crítica de políticas públicas, como feito pela Secretaria de Planejamento, Ciência e Tecnologia do estado da Bahia (1999).

A matriz SWOT, quando utilizada para o planejamento estratégico, permite avaliar a posição de determinada empresa no mercado, elencando suas forças e fraquezas, oportunidades e ameaças, permitindo a tomada de decisões estratégicas (TRAVASSOS \& VIEIRA, 2011). As forças e fraquezas referem-se ao ambiente interno da empresa, enquanto as oportunidades e ameaças ao ambiente externo. $O$ que se encontra dentro do ambiente interno pode ser controlado e alterado, conforme decisões da empresa, já os pontos existentes no ambiente externo devem ser monitorados, visando o menor impacto nos negócios (MACERON FILHO, et al., 2014). 
Para a análise SWOT do Programa de Rotulagem Ambiental Tipo III-DAP, publicado recentemente pelo INMETRO, o ambiente interno refere-se ao próprio texto do regulamento, enquanto o ambiente externo relaciona o público-alvo e demais órgãos do governo na implementação do Programa. Assim, foram levantadas e analisadas as forças e fraquezas do regulamento que instituiu 0 Programa e as ameaças e oportunidades na implementação da política de Declaração Ambiental de Produtos no Brasil.

Foram ainda realizadas entrevistas com representantes de órgãos governamentais e da indústria. As entrevistas realizadas serviram como base para essa pesquisa, por apresentarem um histórico do processo no INMETRO e dar uma visão dos atores que sofrem os impactos do programa brasileiro de DAP proposto.

Foram selecionados para as entrevistas o responsável pela política de DAP (INMETRO), o representante do setor industrial, a Confederação Nacional da Indústria - $\mathrm{CNI}$ - e uma empresa do setor de cosmético, setor alvo deste trabalho. Foi ainda realizada uma entrevista com uma entidade de classe (PROCOBRE) que já adotou da DAP, de acordo com a norma ISO 14025.

Para as entrevistas com o setor privado foram elaborados roteiros específicos (Anexo I), com perguntas abertas, permitindo ao entrevistado conceder o maior número possível de informação e o seu detalhamento. Já para - INMETRO a entrevista não teve roteiro específico, por se tratar de um relato do histórico de elaboração do regulamento. As entrevistas foram gravadas com autorização dos entrevistados e posteriormente transcritas. Os textos foram elaborados a partir destas transcrições.

As entrevistas aconteceram com a responsável pela elaboração do sistema de DAP no Brasil, Sra. Maria Aparecida Martinelli, do Instituto Nacional de Metrologia, Qualidade e Tecnologia (INMETRO). Ainda foram entrevistados os representantes da indústria, Sr. Mario Cardoso, da Confederação Nacional da Indústria (CNI); o Sr. Keyvan Macedo, responsável pela área de sustentabilidade de Marcas e Produtos (Natura); e o Sr. Antonio Maschietto (PROCOBRE).

Foi realizada entrevista com uma indústria química fornecedora de matérias-primas para o setor de cosméticos e higiene pessoal, e que tem implementada a Análise do Ciclo de Vida de seus produtos, a fim de identificar as demandas das empresas do setor estudado e a situação atual da ACV no 
Brasil para o setor privado. Neste caso, a empresa não está sendo identificada, pois a autorização para ser nomeada não foi concedida. 


\section{CONCEITOS}

O entendimento de alguns conceitos é essencial para a compreensão deste trabalho. Este capítulo abordará esses conceitos, dando subsídio aos leitores para melhor entendimento da dissertação.

\subsection{Avaliação do Ciclo de Vida e o Processo Produtivo}

Os estudos de Avaliação do Ciclo de Vida (ACV) surgiram na década de 60, quando se observou o aumento do consumo e a crise do petróleo. Os primeiros estudos abordavam apenas as questões relacionadas à energia, sendo chamados de "análise de energia". Apenas na década de 90 que os estudos começaram a ter a abrangência e o nome conhecidos atualmente (COLTRO, 2007; SILVA, 2013).

A ACV é uma ferramenta qualitativa e quantitativa para a identificação de impactos do processo, produto ou serviço no meio ambiente. Tem por objetivo auxiliar as empresas na identificação de possíveis melhorias no seu processo produtivo e produto, além de fornecer informações importantes para a tomada de decisão, tanto das empresas como do consumidor (BARBOSA JÚNIOR et al., 2008).

Essa metodologia pode também ser expandida para análises relacionadas às questões sociais como de saúde humana e educação abarcando, consequentemente, o desenvolvimento econômico, contemplando os três pilares da sustentabilidade (NORRIS et al., 2005).

Ao se levar em consideração os aspectos sociais na avaliação do ciclo de vida do produto deve-se ter em mente que estes indicadores irão variar de acordo com as especificidades regionais, ao contrário da ACV ambiental, que muitas vezes apresenta dados com médias regionais ou globais. Esse aspecto pode ser um fator de complexidade para a análise (HUNKELER, 2006).

Os estudos de ACV são compostos basicamente por 4 fases, conforme definido nas normas ISO 14040 e 14044: a) definição de escopo e objetivo: determina-se o "limite" da ACV, estabelecendo os dados de produção que devem ser coletados e suas unidades funcionais; b) análise do inventário: o inventário 
é elaborado a partir dos dados coletados e nesta etapa analisa-se as interações do processo e do produto com o meio ambiente; c) avaliação do impacto: identifica e avalia os potenciais impactos que o produto pode causar no meio ambiente, permitindo mudanças no processo; e, d) interpretação: perpassa todas as etapas e garante a conclusão do estudo (IBICT, 2014).

Algumas dificuldades podem ser encontradas durante as fases descritas anteriormente. Por exemplo, os dados provenientes de outras instituições ou empresas podem ser inconsistentes ou demorar a serem apresentados ou ainda estes dados podem não ser compartilhados (BALDO et al., 2002).

No Brasil, a maior dificuldade ainda está em alimentar o banco de dados que teve sua construção iniciada em 2010 pelo Instituto Brasileiro de Informação em Ciência e Tecnologia (IBICT), uma vez que poucas empresas utilizam a ferramenta, dificultando a geração de dados e o compartilhamento de informações.

Em entrevista realizada foi identificada a dificuldade das empresas em conseguir dados para gerar suas ACV. Se faz necessária a ampliação do número de inventários disponíveis, mas a empresa observa um esforço do governo brasileiro em ampliar essas informações. No caso específico do entrevistado como o Brasil ainda não tem dados suficientes para o setor químico, utiliza-se informações de banco de dados internacionais, adaptados à realidade brasileira.

Outra questão apontada pelo entrevistado foi a dificuldade de compartilhar informações geradas com a ACV, já que muitos dados são confidenciais ou sensíveis, não podendo ser divulgada para os concorrentes. Por esta razão, banco de dados públicos são necessários.

Outra dificuldade para o uso da ACV pelas empresas brasileiras é o alto custo de sua execução (SILVA, 2013). A redução do escopo ao processo e a aplicação do pensamento do ciclo de vida nas empresas brasileiras, pode ser um primeiro passo para a consolidação da ACV no Brasil.

A ACV traz diversos benefícios para as empresas que a aplicam. Dentre os benefícios está a possibilidade de identificação de possíveis melhorias no design do produto; economia, a partir da eliminação ou redução dos impactos ambientais; melhoria do processo produtivo; e, obtenção de informações ambientais e de sustentabilidade, permitindo o aperfeiçoamento da interface da empresa com seus públicos-alvo (BARRETO et al., 2007). 
Como será visto adiante, a Avaliação do Ciclo de Vida torna-se importante e pode ter seu uso disseminado, uma vez que a ferramenta gera informações passadas ao consumidor através da Declaração Ambiental do Produto (DAP) e sua rotulagem, permitindo a comparação entre produtos (SCHAU; FET, 2008).

\subsection{Rotulagem Ambiental e Declaração Ambiental do Produto}

A rotulagem é o instrumento de comunicação e informação de determinado produto ou serviço com o consumidor (IPEA, 2011). A rotulagem ambiental tem como objetivo fomentar a oferta e procura de produtos mais sustentáveis através de informação confiável e verificável, em alguns casos, baseada no ciclo de vida dos produtos (TRINDADE, [s.d.]). Isto pode auxiliar os consumidores no entendimento sobre o impacto de seu consumo no meio ambiente e nas questões sociais, dependendo da informação que se tiver.

A rotulagem ambiental pode dar à empresa a diferenciação de seu produto, além de induzir ou efetivamente requerer a adoção de tecnologias mais sustentáveis nos seus processos produtivos, podendo reduzir os custos ambientais do negócio (AMACHER et al, 2004).

Podem ser enumerados três tipos de rotulagem ambiental. O rótulo tipo I, certificado por terceira parte (processo e produto), traz informações relacionadas a qualidade ambiental e permite a comparação entre produtos. Baseia-se na ISO 14021 e geralmente é suportado pelo governo, é o caso, por exemplo, do selo PROCEL de energia. A rotulagem tipo II é auto declaratória com informações fornecidas pelo fabricante, importador ou distribuidor e refere-se à algum apelo ambiental específico, como por exemplo, o selo de embalagem reciclável (Figura 1). Os requisitos para o uso desta rotulagem estão descritos na ISO 14024 (GALLASTEGUI, 2002).

Já o rótulo ambiental tipo III é elaborado com base em informações quantificáveis e verificáveis, por organismo de terceira parte, com parâmetros pré-determinados nas normas ISO 14040 e ISO 14044, e seus requisitos específicos definidos na ISO 14025 (Idem, 2002; INMETRO, 2016). É este tipo de rotulagem o alvo deste trabalho. 


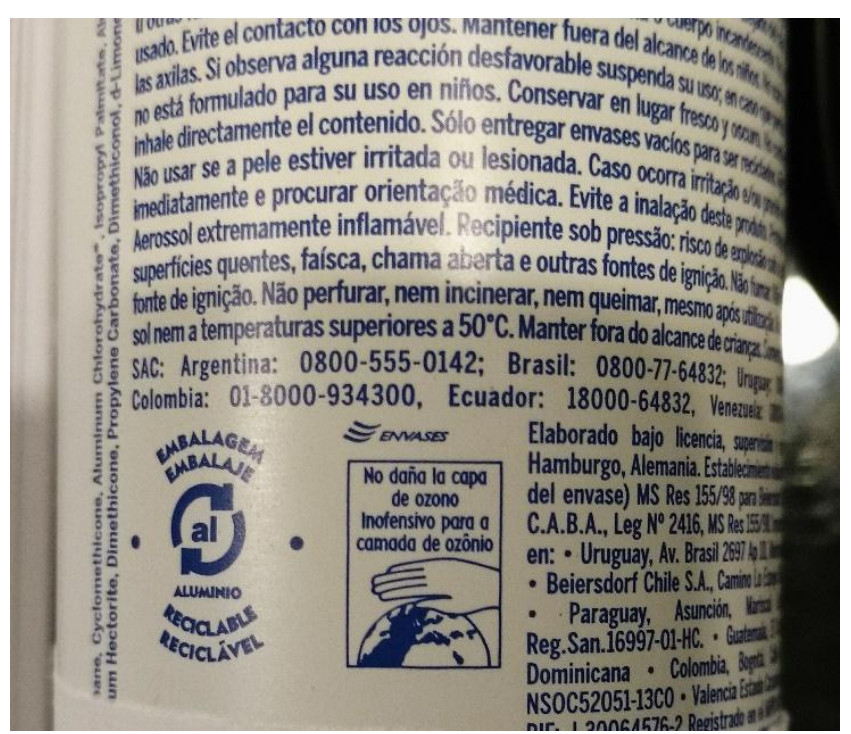

Figura 1: Exemplo de selos usados na rotulagem tipo II. Fonte: Foto de autoria própria. Produto: desodorante aerossol.

A rotulagem ambiental tipo III surge com um forte objetivo de direcionar a produção e o consumo para um caminho mais sustentável. A partir da abordagem da Avaliação do Ciclo de Vida (ACV) do produto e do levantamento dos impactos ambientais causados pelo processo produtivo é possível mudar este processo para que ele gere menos impacto para o meio ambiente, mais seguro para saúde do trabalhador e mais eficiente na relação custo-benefício.

A rotulagem tipo III deve ser elaborada a partir da Declaração Ambiental do Produto (DAP). Para a concepção da DAP é preciso informações advindas da ACV e das Regras de Categorias de Produtos (RCP), conforme exigido pela norma ISO 14025 (DEL BORGHI, 2013).

De acordo com o regulamento do Instituto Nacional de Metrologia, Qualidade e Tecnologia - INMETRO - (2016, p.2) a DAP é "um documento que resume o perfil ambiental de um componente, produto ou serviço, fornecendo informações sobre suas propriedades ambientais de forma padronizada e objetiva". A norma ISO 14025 define DAP como sendo documento que reúne informações ambientais quantificáveis para um produto, com parâmetros prédeterminados, baseados na série de normas ISO 14040, podendo ser complementado por outras informações quantitativas e qualitativas (BINAGHI et al, 2007; ISO, 2015; SANTOS, 2012). 
A formulação da DAP depende dos requisitos gerais definidos em sua norma e dos requisitos específicos previstos nas Regras de Categoria de Produtos (RCP).

A RCP é definida pelo INMETRO, conforme regulamento, como sendo um "conjunto de regras, requisitos e diretrizes específicas para desenvolver as declarações ambientais do tipo III para uma ou várias categorias de produto" (INMETRO, 2016, p. 9). A norma ISO 14025 define as Regras de Categoria de Produtos como sendo a base para a Declaração Ambiental de Produto, pois determina como serão conduzidas as ACV, assegura a homogeneidade metodológica, permitindo a comparação das informações declaradas, e define os requisitos presentes na DAP (FET et al, 2009; ISO, 2015; SANTOS, 2012).

De acordo com a norma ISO 14025 (2015) e SANTOS (2012), deve-se conter, minimamente, em uma RCP os seguintes dados:

> Definição e descrição da categoria do produto: função, comportamento técnico e uso;

$>$ Definição dos objetivos e alcance da ACV: unidade declarada ou funcional, limites do sistema, descrição dos dados, critério para inclusão de entradas e saídas, requisitos de qualidade dos dados (confiabilidade), categorias do impacto ambiental e substâncias informadas;

Análise de inventário: compilação de dados, procedimentos de cálculos, fluxos e emissões de matéria e energia;

$>$ Outros conteúdos: seleção de categorias de impacto e regras de cálculo, parâmetros pré-determinados de dados de ACV, materiais e substâncias, conteúdo e formato da DAP, e validade.

As RCP somente são concebidas com as informações disponíveis nos inventários de ciclo de vida de produtos.

A rotulagem tipo III pode ser disponibilizada no rótulo do produto, em forma de texto ou elemento gráfico, na embalagem do produto ou em informes sobre o mesmo (INMETRO, 2016). 


\section{ESTADO DA ARTE - OS SISTEMAS DE DECLARAÇÃO AMBIENTAL DE PRODUTO NO MUNDO E SUA IMPLEMENTAÇÃO A PARTIR DE POLÍTICAS DE INCENTIVO}

Este capítulo abordará os sistemas de Declaração Ambiental de Produto e rotulagem ambiental tipo III de alguns países do mundo. Para seleção dos modelos, foram avaliados os países em que os programas já estão consolidados, como é o caso dos países europeus e naqueles em que os programas podem ser considerados ainda recentes, incluindo os sistemas dos países em desenvolvimento que guardam certa semelhança com o Brasil.

Seus programas foram analisados conforme disponibilidade de referências bibliográficas, já que não há tantas referências que descrevem os sistemas existentes, como também identificado nas pesquisas realizadas por Minkov et al. (2015).

O sistema brasileiro não está abarcado neste capítulo, pois o capítulo seguinte é dedicado a ele.

\subsection{Os Sistemas de Declaração Ambiental de Produto no Mundo}

Para o desenvolvimento de um sistema de DAP são necessárias algumas etapas. Primeiro é preciso que o país tenha um programa de rotulagem ambiental, com um operador determinado, responsável pelo sistema. Depois inicia-se a elaboração das Regras de Categoria de Produtos, para a partir daí elaborar a DAP (SANTOS, 2012).

De acordo com o Ecolabel Index 4 , atualmente, 199 países apresentam sistema de rotulagem ambiental, havendo 465 rótulos ambientais registrados no diretório, sendo que desses, 66 se aplicam ao setor de cosméticos e produtos de higiene pessoal. Vale ressaltar que o diretório registra todos os tipos de rotulagem ambiental previstos pela norma ISO e não apenas as declarações ambientais de produtos (rotulagem tipo III).

Em pesquisa realizada por Gruère (2013), baseado no cruzamento dos dados disponíveis no diretório Ecolabel Index e no banco de rotulagem e

4 Ecolabel Index: diretório global de rotulagem ambiental. Disponível em www.ecolabelindex.com. 
informação ambiental (ELIS 5 ), dos 544 tipos de selos ambientais analisados (criados entre 1970 e 2012), apenas 26 eram do tipo III, conforme ISO 14025, e somente 90 utilizavam a ACV como metodologia. O crescimento dos rótulos tipo III, porém, pode ser considerado significativo, já que de 2000 a 2012, houve um crescimento de $5 \%$ na utilização deste tipo de rotulagem. Grande parte dos programas são oriundos e administrados por organizações sem fins lucrativos (266), sendo sua utilização voluntária. Dos rótulos analisados, 26 estavam voltados para o setor de cosméticos e higiene. A maioria dos programas concentram-se nos países da Europa (215), seguidos pela América do Norte (205).

Hunsager et al (2014) verificou em sua pesquisa que de 27 programas de DAP analisados, existiam 556 regras de categorias de produtos, destes $66 \%$ oriundos de programas públicos e a maioria aplicável ao setor da construção (13 programas).

Atualizando a pesquisa do autor supracitado, Minkov et al. (2015), identificou 39 programas de DAP espalhados por diversos países do mundo, incluindo Japão, EUA, Canadá e França. Dos 39 programas, 56\% encontram-se na Europa e $28 \%$ na América do Norte; do total $54 \%$ são de âmbito internacional; e, a maioria dos programas, $44 \%$, são aplicáveis aos setores em geral. Ou seja, a maioria dos programas de rotulagem ambiental tipo III que tiveram início através dos produtos destinados ao setor da construção, ao longo do tempo, com o amadurecimento dos sistemas, foram ampliados para os demais setores atingindo os produtos voltados para o consumidor de maneira geral.

\section{Europa}

Pode-se dizer que foi nos países europeus que a rotulagem ambiental tipo III começou mais forte, dado o histórico de rotulagem já existente no local. A primeira rotulagem ambiental que se tem notícia surgiu na Alemanha, em 1970, e permitia ao consumidor identificar o produto com baixa toxicidade e advindos da reciclagem, atestado pela Agência Ambiental do país (MOURA, 2013).

\footnotetext{
${ }^{5}$ ELIS: Environmental Labelling and Information Schemes.
} 
Em 2000, a União Europeia (UE) editou o primeiro regulamento (EC ํo 1980/2000) que tratava de rotulagem ambiental, já baseado no ciclo de vida do produto e capaz de mostrar para os consumidores o impacto dos produtos. Este programa era voluntário e, ainda assim, foi observada uma grande adesão por parte das empresas. Com os ganhos apresentados por essa experiência, em 2010 a UE editou novo regulamento, substituindo o anterior, EC ํo 66/2010, alinhado com a política de produção e consumo sustentáveis do país e com a política de eco design e energia. Este novo regulamento dá as diretrizes gerais para os estados partes regulamentares $O$ uso da rotulagem ambiental e as penalidades nos casos de não cumprimento das exigências (UNIÃO EUROPEIA, 2010).

As informações obtidas com a ACV do produto e disponibilizadas no rótulo dos produtos deve ser de fácil entendimento, significativa e capaz de direcionar o mercado. Com o regulamento de 2010 a UE estendeu a rotulagem ambiental para todos os produtos, exceto alimentos, por entender que para esses já existe um selo específico (orgânicos) e seria necessária uma análise mais profunda para garantir a agregação de valor das informações para o consumidor.

O sistema previsto no regulamento EC ํㅡ 66/2010 deixa a cargo dos estados partes a definição de um operador, desde que este seja neutro e garanta a transparência do processo. Um Conselho para rotulagem ambiental da União Europeia foi estabelecido para subsidiar a Comissão de rotulagem ambiental, contribuindo no desenvolvimento e revisão dos critérios e requisitos mínimos do desempenho dos produtos, além de revisar o próprio programa.

Critérios relacionados a mudanças climáticas, biodiversidade (uso e impacto), resíduos, energia, poluição e perigos das substâncias presentes nos produtos foram classificados pelo regulamento como impactos ambientais significativos, sendo requisitos gerais. Demais critérios podem ser propostos e avaliados pelo Conselho, sendo publicados no diário oficial da UE, e as análises não podem levar mais do que nove meses para serem publicadas.

A Comissão deve estabelecer três características ambientais para cada categoria de produto, que figurará como informação opcional na rotulagem. Além disso, é a responsável por definir a validade dos requisitos estabelecidos e o grau de variação dos produtos da mesma categoria, em que estes requisitos ainda se aplicarão. 


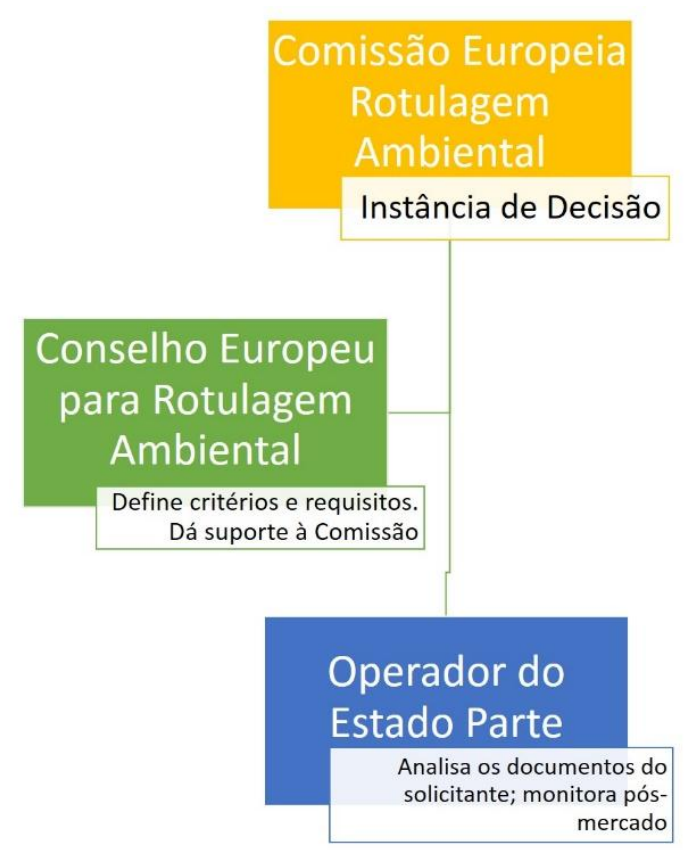

Figura 2: Estrutura da Comissão Europeia para Rotulagem Ambiental. Fonte: Autoria própria, com base em UNIÃO EUROPEIA (2010).

A empresa interessada em obter a rotulagem ambiental da UE deve encaminhar os documentos necessários para o Estado Parte responsável (no país de origem do produto, caso seja um produtor local, ou no país em que o produto será comercializado, no caso de produto exportado de países fora do bloco). O operador responsável verificará os documentos enviados, checando a conformidade das informações com os requisitos e critérios determinados no programa. Estando conforme, é concedida a autorização para o uso do selo pela empresa.

A empresa pode perder o direito do uso, caso seja comprovado que seus produtos deixaram de cumprir com os requisitos e critérios determinados. As denúncias recebidas sobre o produto são investigadas e é concedida à empresa a possibilidade de sua defesa. O operador que suspender o direito ao uso do selo da empresa deve comunicar os demais Estados Parte, garantindo assim a harmonização do entendimento.

\section{Suécia}

Na Suécia o programa de Declaração Ambiental de Produto teve início em 1997, com o estímulo do setor privado, sendo desenvolvido em parceria com órgãos de governo. O programa é gerido por um conselho responsável por 
orientar quanto ao sistema, inclusive através da publicação de manuais, e dar publicidade às declarações de produtos elaboradas. Além do conselho gestor, há dois comitês, um consultivo (formado por governo, organizações não governamentais, empresas, organismos de certificação e representantes dos consumidores) e outro técnico, formado por especialistas em ciclo de vida, que produzem guias específicos para produtos e avaliam metodologias em ACV, atualizando-as (BOGESKÄR et al., 2002).

$O$ operador do sistema na Suécia é o EPD International $A B$, parte do International EPD System ${ }^{6}$, operador que concentra e harmoniza diversos sistemas no mundo. $O$ operador tem por obrigação exercer a secretaria, gerir o comitê técnico e o conselho internacional. Dado o tempo de existência e o papel de protagonista assumido pela Suécia, o International EPD System, publica manuais e guias capazes de auxiliar os países na implementação de seus programas, garantindo uma harmonização (INTERNATIONAL EPD SYSTEM, 2015).

Para o sistema, as Regras de Categorias de Produtos devem ser desenvolvidas conforme requisitos da ISO 14025 e a estrutura segue como padrão o sistema de classificação de produtos da ONU, denominado Central Product Classification, dando abertura para a complementação com base em outros sistemas, como denominação de compras públicas. As RCP devem ser elaboradas com base nas informações dos inventários de ACV, incluindo a interpretação das informações disponíveis no inventário, limitando o escopo da ACV e seus impactos. Nos casos em que a base de dados da ACV influenciará nos resultados, pode ser definido pelo operador a base de dados a ser utilizada pelo usuário. Durante a elaboração das RCP, caso haja interesse, a empresa que está desenvolvendo a DAP pode realizar uma pré-certificação durante o processo, permitindo uma avaliação previa do documento, e, consequentemente, uma revisão, caso necessário (Idem, 2015).

Depois de elaboradas, as RCP passam por uma fase de consulta, na qual são avaliadas pelo conselho consultivo, antes de seguir para a aprovação. Após essa primeira análise, as RCP são aprovadas pelo comitê técnico e publicadas pelo operador. Elaborada a RCP, a DAP pode ser criada, pela empresa

${ }^{6}$ The EPD International System: operador de sistema que congrega boa parte dos programas de Declaração Ambiental de Produtos no mundo. Sua matriz localiza-se na Suécia. 
demandante, seguindo os requisitos previstos pelo operador do sistema na Suécia, sendo verificada por terceira parte.

\section{Alemanha}

Na Alemanha, o sistema de declaração ambiental de produtos começou com a adaptação das rotulagens tipo I e tipo Il já utilizadas no país. A estagnação na evolução do programa Blue Angel (rotulagem tipo I), levou o país a reformulálo, iniciando-se a utilização do pensamento em ciclo de vida no momento de definição de critérios para a rotulagem. Em um segundo momento, alguns setores substituíram o sistema Blue Angel por requisitos da ISO 14025, iniciando a utilização da DAP (BOGESKÄR et al., 2002).

Assim como em muitos outros países, a DAP e a rotulagem tipo III na Alemanha é forte no setor da construção civil. Um dos operadores do sistema na Alemanha é a International EPD System. A lógica é a mesma de dos demais sistemas, sendo elaborada uma RCP e posteriormente uma DAP. Há outros operadores, como o Instituto Bauen, responsável por certificar e registrar as Declarações.

\section{França}

$\mathrm{Na}$ França, a rotulagem tipo III é obrigatória desde 2009, quando foi publicada a primeira versão da Lei Grenelle, revista em 2010. Foi neste ano que a implementação da rotulagem passou a ocorrer. Esta Lei trouxe diversas iniciativas ambientais, que deveriam ser implementadas pelo governo e pela sociedade, visando o desenvolvimento sustentável do país. Dentre as iniciativas estão ações voltadas para mudanças climáticas, conservação da biodiversidade e florestas, prevenção de riscos ambientais e informação ao consumidor.

O programa francês é uma parceria entre o governo (através da ADEME - Agência francesa de meio ambiente e energia) e a entidade normativa AFNOR (similar a ABNT, no Brasil). A ideia é levar, de maneira harmonizada e confiável, informações sobre impactos ambientais de produtos aos consumidores. Assim, ficou definido pela AFNOR como princípios da rotulagem ambiental: disponibilidade da informação, padronização da forma como a informação é 
disponibilizada e métodos de cálculo do impacto idênticos, tendo a mesma base para a geração da informação (AFNOR, [s.d.]).

Para elaboração da DAP são utilizados os critérios definidos pela AFNOR, a partir de negociações entre fabricantes, governo e entidades de defesa dos consumidores e do meio ambiente. As DAP são certificadas por uma terceira parte e, caso não haja uma RCP para a categoria, o interessado pode solicitar à AFNOR sua elaboração. A AFNOR avalia os dados enviados pelo interessado e verifica se o produto segue os critérios estabelecidos. Em estando tudo certo, é concedida a rotulagem e o registro da DAP (AFNOR, [s.d.]).

A obrigatoriedade do uso da rotulagem ambiental parece ter funcionado. Em 2010, foram solicitadas trezentas avaliações de produtos em geral, com a disponibilização de rotulagem ambiental (BORLOO, 2010).

\section{JAPÃO}

No Japão, o uso da rotulagem tipo III pelas empresas é uma estratégia governamental para tornar o consumidor mais consciente e mudar o padrão de consumo da população, através do fornecimento ao consumidor de informações necessárias sobre os produtos, baseada na sua avaliação do ciclo de vida, garantindo a melhor decisão de compra (JEMAl, 2001). O projeto piloto do programa de rotulagem denominado ECOLEAF teve início em 1998, por uma iniciativa governamental, através da associação de gerenciamento ambiental ${ }^{7}$ do país, ligada ao Ministério da Indústria (BOGESKÄR et al., 2002). Em 2001, após diversos experimentos, o programa passou a ser definitivo, sendo aplicado em larga escala.

No programa ECOLEAF, o rótulo ambiental é certificado, garantindo a veracidade das informações e a transparência. As declarações apresentam informações como consumo de energia e recursos naturais, segurança do produto, material de embalagem, cumprimento de requisitos legais, ciclo de vida, impactos ambientais, entre outras (BOGESKÄR et al., 2002).

Nesse modelo, o setor interessado propõe a confecção das regras de categoria do produto $(\mathrm{RCP})$ para $\mathrm{o}$ grupo de trabalho, que prepara a versão

7 JEMAI: Japan Environmental Management Association for Industry (órgão ligado ao Ministério da Economia, Comércio e Indústria, do país). 
preliminar da RCP e encaminha para um painel de especialistas revisar. Após a aprovação da RCP, a empresa faz a declaração ambiental (DAP) e a rotulagem do produto, submetendo-os para verificação externa ou verificação interna. No caso da verificação externa, um organismo de terceira parte audita a rotulagem e, sendo aprovado, registra e a torna pública. Já para o caso da verificação interna, os requisitos para a confecção da rotulagem são auditados e o relatório da auditoria interna encaminhado para um painel verificador. Havendo aprovação o sistema é certificado e a rotulagem registrada e publicada como auto verificada (JEMAI, 2001). O diagrama ilustrado na figura 2 apresenta 0 processo do sistema DAP Japonês.

Há ainda a possibilidade de se utilizar, ao invés de uma RCP específica, um modelo básico de regras, aplicáveis a todas as categorias de produtos, elaborada pelo operador do sistema. São utilizados dados dos inventários de ciclo de vida (JEMAI, 2013).

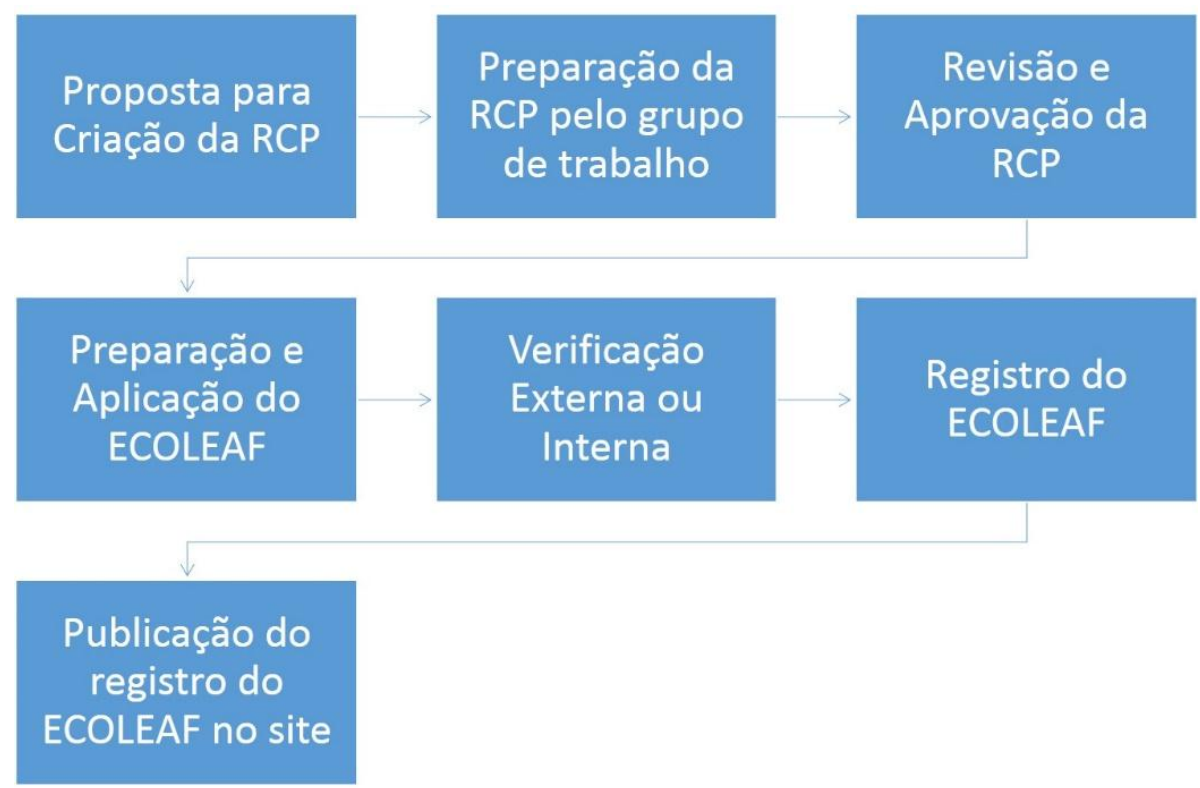

Figura 3: Sistema de DAP ECOLEAF, Japão. Fonte: JEMAI, 2001.

Para os cálculos do inventário de dados do ECOLEAF duas categorias são consideradas essenciais pelo JEMAl: consumo e descarte do produto. Em consumo são dois critérios observados: uso de recursos renováveis e de não renováveis. Já para descarte são três critérios: emissões atmosféricas, efluentes e resíduos (JEMAI, 2013). 
Para a avaliação dos impactos ambientais, utiliza-se duas categorias: consumo e descarte ambiental. Novamente em consumo são dois critérios: fonte de energia e fonte de redução de carga mineral. Em descarte no meio ambiente são outros dois critérios, aquecimento global e acidificação da atmosfera, e eutrofização dos corpos d'água (JEMAI, 2013).

Três fichas devem ser geradas pela empresa ao final do processo: uma declaração de aspectos ambientais, com informações quantitativas dos aspectos, de maneira que completa e fácil de entender para o consumidor do produto (seja empresa, seja pessoa física); uma DAP, com todas as informações; e, uma ficha de informações do produto (a RCP) (JEMAI, 2013).

\section{Coréia do Sul}

Com o objetivo de auxiliar os consumidores na escolha de produtos com menor impacto ambiental a Coréia do Sul começou seu programa de rotulagem tipo III em 1997, a partir de uma iniciativa governamental, apoiada por entidades representantes do setor privado. O país desenvolveu seu banco de dados em ACV, através da academia e conduziu projetos piloto em ciclo de vida para orientar a discussão e metodologia em rotulagem tipo III. Assim como no Brasil, o programa de rotulagem da Coréia foi alvo de uma legislação, do Ministério do Meio Ambiente, apesar de ser um sistema voluntário (BOGESKÄR et al., 2002; KEITI, [s.d.]).

Atualmente, são 147 categorias de produtos e 03 de serviços que fazem parte do programa. As empresas produzem as declarações que são verificadas por auditoria e publicadas pelo Korea Environmental Industry \& Technology Institute (KEITI), órgão ligado ao Ministério do Meio Ambiente do país. A certificação da DAP é pedida pela empresa interessada, um grupo de estudo formado por 03 profissionais (02 em ACV e 01 em certificação de processos ou meio ambiente) avalia o pedido e os documentos, gerando um relatório que é encaminhado para uma banca examinadora, composta por especialistas em ACV, rotulagem ambiental e especialistas em produtos. Essa banca expressa sua opinião sobre o pleito da empresa, concedendo ou não a certificação da DAP. A DAP é então publicada pelo KEITI. 
A Coréia do Sul na implementação de seu sistema de rotulagem tipo III tomou o cuidado de construir uma infraestrutura para que as empresas interessadas pudessem aplicar a política proposta. Foi desenvolvido um banco de dados em ACV, profissionais foram formados para utilizar a ferramenta de ciclo de vida, os organismos certificadores foram treinados, garantindo assim a possibilidade de implementação da legislação em vigor (BOGESKÄR et al., 2002).

O KEITI faz parte do Global Ecolabelling Network (GEN), visando a harmonização da rotulagem ambiental, permitindo um reconhecimento mútuo, facilitando a comercialização de produtos entre países.

Para o estímulo ao uso da rotulagem tipo III e um consumo mais sustentável, a Coréia do Sul integrou essa política com outras, como compras públicas sustentáveis, lojas verdes, centros de consumo sustentável e campanhas de estímulo para produtos "ambientalmente amigáveis".

Na questão de compras públicas sustentáveis, por exemplo, há órgãos governamentais que exigem a certificação de produtos para a aquisição. É neste sentido que essa política contribui para a ampliação do uso da rotulagem ambiental.

Atualmente, o foco da Coréia do Sul tem sido a rotulagem ambiental voltada à pegada de carbono, tendo uma queda no número de solicitações por empresas.

\section{China}

Não há disponível muitas informações sobre o sistema de rotulagem da China. As informações disponíveis foram encontradas na página do Environment and Development Fundation.

Operado por uma entidade, sem fins lucrativos, chamada Environment and Development Fundation (EDF), o sistema é governamental, voluntário e tem por objetivo garantir a entrada dos produtos chineses em países que exijam as informações de impactos ambientais do produto.

Parte do International EPD System, o EDF é o responsável por certificar as DAP das empresas chinesas e daquelas que querem comercializar produtos 
no mercado chinês. Portanto, o programa é internacional. Após a certificação a DAP é submetida ao International EPD System, onde é reconhecido e publicado.

\section{Índia}

$\mathrm{Na}$ Índia, o sistema de rotulagem ambiental começou em 1991, por iniciativa governamental (Ministério do Meio Ambiente e Florestas), com o objetivo de identificar produtos ambientalmente amigáveis. O sistema denominado ECO Mark, leva em consideração a ACV dos produtos e é aplicável a qualquer categoria, inclusive produtos de consumo, permitindo às empresas identificarem seus impactos ambientais e aos consumidores escolherem produtos mais sustentáveis (SHARMA \& KURANI, 2004).

Quando publicada a exigência do ECO Mark para o setor privado foi definida pelo órgão de governo uma lista de produtos de consumo que deveriam apresentar a rotulagem, dentre eles, os produtos cosméticos. Definiu-se como operador o organismo normatizador do país, denominado Bureau of Indian Standarts (BIS), responsável por definir os requisitos ambientais necessários para cumprimento pelos produtos e certifica-los seguindo estes requisitos (MINISTRY OF ENVIRONMENT AND FOREST, [s.d.]).

No programa ECO Mark as RCP e DAP passam pela avaliação de dois comitês, um de Direção, formado pelo governo (Ministério), secretarias de estado e partes interessadas convidadas; e outro técnico, composto por órgão técnico do governo (Órgão Central de Controle de Poluição) e representantes da indústria, comércio, academia e instituições normativas; e um organismo responsável por verificar e certificar as Declarações, o BIS. Como nos demais programas são avaliados os impactos do produto no ambiente e os impactos gerados no processo produtivo (NAIME, 2013; SHARMA \& KURANI, 2004).

Após o início do programa, em 1992, o governo indiano publicou uma resolução, direcionando cada categoria de produto cosmético para uma norma diferente do BIS, em que é possível se observar os requisitos ambientais que devem ser cumpridos por eles. Além disso, o regulamento dispõe dos ingredientes que podem ou não ser utilizados em cosméticos, material de embalagem e a abordagem sobre alguns requisitos específicos, tais como, testes dermatológicos, biodegradabiliade de surfactantes e metais pesados. 
Ainda, permite ao BIS a elaboração de mais requisitos, caso o órgão julgue necessário (MINISTRY OF ENVIRONMENT AND FOREST, 1992).

\section{Canadá}

O sistema Canadense de rotulagem ambiental tipo III existe desde 1996. Denominado "Environmental Profile Data Sheet - EPDS" (Ficha de Informação de Perfil Ambiental), foi desenvolvido inicialmente para o setor de papel e celulose, pela Associação ${ }^{8}$ setorial e uma organização não governamental, ou seja, o programa é de iniciativa privada. Por ter iniciado com foco no processo produtivo e tendo como público-alvo outras empresas, a certificação do programa permite a identificação do produto como sendo de menor impacto, quando comparado aos demais, permitindo a melhor escolha por parte dos clientes (BOGESKÄR et al., 2002).

O programa do Canadá foi desenvolvido e persistiu por uma demanda de marcado, em que os compradores, ao longo de toda cadeia produtiva, têm buscado mais transparência e informações a respeito das ações de sustentabilidade da empresa e dos impactos no processo. A DAP, utilizando a ACV para gerar informações sobre o processo produtivo a partir de alguns indicadores específicos, tal como gases do efeito estufa, pode demonstrar para os clientes e consumidores esses impactos, antes desconhecidos (CSA GROUP, [s.d.]; SALAZAR, 2004).

Ainda voluntário, o programa é atualmente gerenciado por uma associação denominada CSA Group, sem fins lucrativos e internacionalmente acreditada. Parte da International EPD System, o programa Canadense está alinhado com outros sistemas internacionais. A Figura 3 apresenta as fases de desenvolvimento e registro da DAP no Canadá.

\footnotetext{
${ }^{8}$ Canadian Pulp and Paper Association.
} 


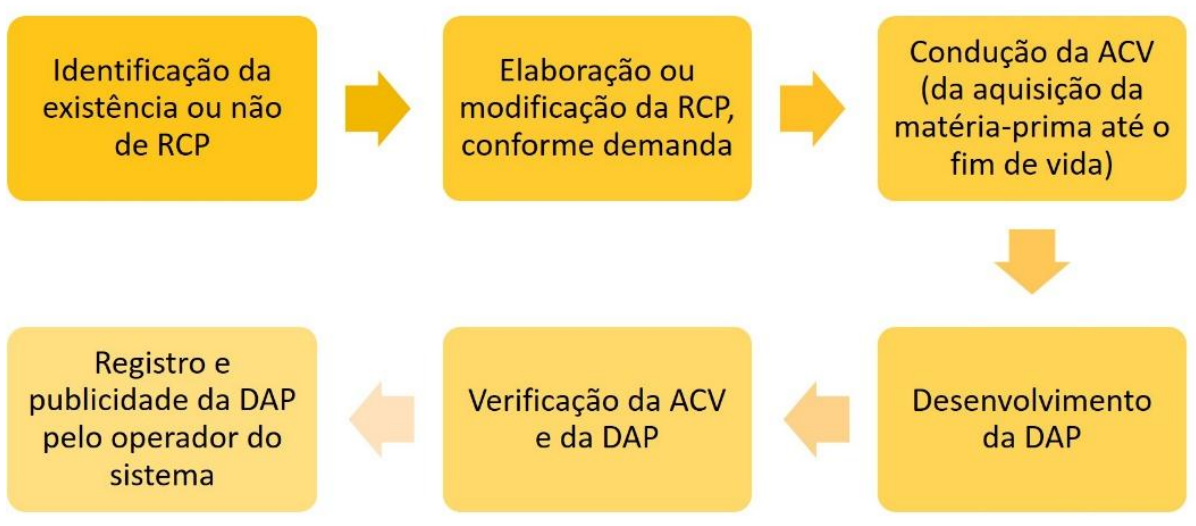

Figura 4: Sistema DAP do Canadá. Fonte: CSA GROUP, [s.d.]

O operador do sistema, nesse caso a CSA Group, auxilia a empresa demandante na identificação da existência ou não das regras de categoria do produto, em existindo uma RCP para o produto ou serviço esta pode ser utilizada tal qual ou adaptada, conforme necessidade. Caso a RCP não exista, o CSA Group auxilia no desenvolvimento de uma RCP. Observa-se que neste modelo de sistema não há um grupo técnico responsável.

Após a confecção ou adaptação da RCP, é conduzida uma ACV que avalia o impacto do produto, desde a entrada da matéria-prima até o descarte do produto, passando pelo processo produtivo. A partir dos dados coletados com a ACV, a declaração ambiental de produto é elaborada, com informações necessárias para o bom entendimento do consumidor. Tanto a ACV como a DAP são verificadas por terceira parte, garantindo a confiabilidade e veracidade das informações. Por fim, a DAP é registrada e publicada pelo operador (CSA Group).

\section{Estados Unidos}

Os Estados Unidos, assim como os demais países do G7, apresentam um programa de rotulagem ambiental, visando a informação do consumidor sobre 0 desempenho ambiental dos produtos disponíveis no mercado. O seu sistema não se encontra descolado dos demais sistemas utilizados no mundo, já que segue as normas da ISO. 
Os programas governamentais para rotulagem existentes são obrigatórios e não são unificados, variando conforme a categoria do produto, tendo como propósito a informação do consumidor sobre os perigos e riscos de um determinado produto. Os programas de rotulagem ambiental são voluntários, acreditados por uma terceira parte, e tem por objetivo identificar os produtos que trazem menos impacto para o meio ambiente. Nos EUA não há um programa único de rotulagem tipo III e em levantamento realizado pelo EPA ${ }^{9}$, em 1998, haviam 09 programas desse tipo no país. De acordo com este mesmo estudo, para o modelo de mercado dos Estados Unidos não faz sentido a existência de um programa único (ENVIRONMENTAL PROTECTION AGENCY, 1998).

A elaboração de uma DAP nos Estados Unidos deve seguir quatro etapas, como na maioria dos programas. Inicialmente, deve ser elaborada a regra de categoria do produto, conforme interesse da empresa, buscando-se utilizar RCP que já existem ou adaptá-las, para, desta forma, manter uma harmonização entre os programas. Um estudo de ACV deve ser realizado, visando obter as informações necessárias sobre o impacto do produto. A partir dos dados obtidos e da RCP elaborada, a DAP é desenvolvida pela empresa, para, por fim, ser verificada por organismo de terceira parte (ATSM, [s.d.]).

Assim como nos demais modelos de rotulagem tipo III, há um comitê decisório, formado pelos principais stakeholders interessados no tema, um comitê técnico, formado por especialistas em ACV, na categoria do produto em discussão e em DAP, e um organismo certificador, responsável por verificar o que foi elaborado.

Apesar de não existir um único programa e os programas não serem governamentais, observa-se o amplo apoio e participação dos órgãos de governo e a integração da rotulagem ambiental com as demais políticas locais.

O que se observa nos programas no mundo é que, apesar da norma ser a mesma, os sistemas nos países têm suas particularidades, o que dificulta 0 reconhecimento mútuo entre eles.

Grande parte dos programas de rotulagem tipo III existentes no mundo cobrem determinadas categorias, como papel, detergentes, construção e

\footnotetext{
${ }^{9}$ EPA: Environmenal Protection Agency.
} 
equipamentos eletrônicos, enquanto que outras categorias tornam-se específicas, conforme necessidade do país, por exemplo, para a exportação de produtos.

Os diferentes programas existentes no mundo ainda não são passíveis de reconhecimento mútuo, dadas as diferenças existentes nos parâmetros determinados, metodologia e atores envolvidos, mas acredita-se que no futuro próximo estes programas estarão alinhados. Algumas iniciativas para este reconhecimento já existem, como o grupo de trabalho para discussão das regras de categorias de produtos (GPCRD - Guidance for Product Category Rules Development); o programa europeu de pegada de carbono (PEF) e um grupo da própria ISO (14027) que tem por objetivo complementar a norma ISO 14025, esclarecendo eventuais dúvidas. O reconhecimento mútuo seria benéfico, pois economizaria tempo e duplicidade de documentos (HUNSAGER et al, 2014; MINKOV et al., 2015).

Vinte e oito programas de rotulagem tipo III já possuem, de alguma maneira, um reconhecimento mútuo, já que se encontram relacionadas em um mesmo gestor de sistema, International EPD System. Dentre esses, Argentina, Canadá, EUA, Japão, França e Suécia. Nesses casos os sistemas são bastante parecidos, uma vez que o operador International EPD System determina alguns requisitos gerais para tornar os sistemas mais alinhados e com as mesmas regras para os cálculos de ACV no maior número possível de categorias de produtos, permitindo a comparação entre eles e o reporte o mais uniforme possível (INTERNATIONAL EPD SYSTEM, 2015).

Subramanian et al. (2012) identificou, em pesquisa com as regras de categorias de produtos disponíveis, que há diversas inconsistências dada a metodologia e requisitos utilizados na elaboração delas. Utilizando uma mesma categoria de produto, comparando as RCP foi possível identificar diferenças no objetivo, nos impactos ambientais e na classificação, tendo em vista a amplitude e informações disponíveis nos estudos de ACV utilizados. A harmonização das regras de categoria se fazem necessárias, uma vez que a tendência é a globalização da rotulagem tipo III, dando ao consumidor, de maneira geral, a oportunidade de verificar o impacto causado por determinado produto.

Está havendo uma internacionalização das regras de categoria e das declarações ambientais de produtos, permitindo assim a ampliação da 
divulgação da informação. Este fator está bastante relacionado à questão da globalização dos mercados e dos novos acordos comerciais entre países. As exigências por produtos de menor impacto ambiental e social, por um consumo consciente e pela convergência regulatória, tende a levar os países a harmonizar os requisitos que devem ser cumpridos pelos produtos, inclusive no que tange a rotulagem.

Ao mesmo tempo que algumas políticas públicas podem estimular o uso da rotulagem tipo III, conforme ISO 14025, outras podem desestimular, como tem ocorrido na Ásia, em que o uso dessa rotulagem tem decrescido, por estar dando lugar ao uso de rotulagem relacionada à pegada de carbono, como no caso do programa Sul Coreano (MINKOV et al., 2015).

\subsection{Políticas Públicas e Iniciativas no mundo: sintonia e integração com a Declaração Ambiental de Produtos}

Ao se analisar os sistemas de DAP nos diferentes países do mundo, observa-se que esses não são isolados, geralmente, fazem parte de outras políticas relacionadas à sustentabilidade ou de programas específicos do governo voltados às questões ambientais ou de comércio.

No caso dos países em desenvolvimento, como na Malásia, Índia e China, ficou claro que a implementação de um sistema de Declaração Ambiental do Produto estava voltada para a exportação dos mesmos, ou seja, a existência de um sistema está totalmente relacionada à inserção dos produtos locais no mercado externo, em países que exigem informações ambientais no rótulo.

Assim, com base nos sistemas analisados, pode-se enumerar as seguintes políticas como sendo as principais para a adoção dos programas de rotulagem tipo III: consumo e produção sustentável; pegada de carbono e mudanças climáticas; geração de resíduos sólidos; compras públicas sustentáveis; e, comércio exterior.

Em estudo realizado com o modelo indiano, Sharma \& Kurani (2004) ressaltam que as DAP não podem ser descartadas como barreiras não-tarifárias, já que os produtos custariam muito mais na exportação, dadas as exigências de certificação de rotulagem, o custo da produção e da própria exportação. Isso 
reduziria a competitividade dos produtos de países em desenvolvimento. Ainda, não existe a clareza de que os compradores em outros países estão preocupados com as questões ambientais acima do preço. Sendo assim, somente se houver a exigência da DAP e rotulagem tipo III nos países compradores é que os fabricantes se interessarão nessa política (ENI \& MATTEI, 2005).

Na Malásia e no Japão, a ideia inicial da rotulagem ambiental era direcionar a melhor escolha de compra do consumidor. A partir de um consumo sustentável e com os levantamentos de dados necessários para a elaboração da DAP ficaria mais fácil mudar os padrões de produção, tornando estes também mais sustentáveis (JEMAI, 2001; RASHID, et al, 2009). Infelizmente, em muitos casos, o consumidor ainda não está preparado para reconhecer a rotulagem ou utilizar as informações disponibilizadas para eles.

No Japão, a rotulagem integra-se com outra política, a de pegada de carbono. Neste caso, é avaliado apenas as emissões de gases do efeito estufa (GEE), deixando-se de lado outros impactos ambientais causados pelo processo ou produto. Da mesma maneira que para a DAP, no programa de pegada de carbono é necessária a elaboração de uma RCP específica para emissões, seguindo o mesmo processo do programa de DAP, até a verificação e publicação das informações pelo operador do sistema (JEMAI, 2013).

De acordo com os documentos levantados, pode-se dizer que a Europa é o continente mais avançado em termos de integração das políticas de sustentabilidade, encaixando a rotulagem tipo III em políticas mais abrangentes de produção e consumo sustentáveis.

A Política de Produção Integrada (Integrated Public Policy - IPP) da Comunidade Europeia teve sua discussão iniciada em 1997 e sua implementação em 2003, com o objetivo de alinhar as ações para disponibilizar no mercado produtos com menos impactos para compra do consumidor. O IPP foi baseado em três princípios: orientação de mercado, comprometimento dos atores envolvidos e abordagem do ciclo de vida. Utilizando este último como ferramenta, foi possível cobrir as duas pontas, a produção e o consumo, desenvolvendo uma economia sustentável, harmonizando as necessidades sociais, econômicas e ambientais (ANDRYKIEWICZ, 2014; CALABRO, 2007; CHARTER et al., 2001; EUROPEAN COMISSION, 2009). 
Levando em consideração a abordagem do ciclo de vida, fez-se necessário, logo após a implementação do IPP, uma revisão e atualização da plataforma do banco de dados em ciclo de vida na Europa. Desta maneira, o banco de dados existente passa por atualizações periódicas, garantindo a disponibilização da melhor informação (EUROPEAN COMISSION, 2009).

No que diz respeito ao processo produtivo, a ideia do IPP é estimular a produção mais limpa, reduzir a geração de resíduos e prevenir a poluição. Já na ponta do consumo, tem um papel de direcionar as escolhas do consumidor (seja empresa, pessoa ou governo) e reduzir os impactos dos produtos e serviços no uso e descarte. Por integrar outras políticas já existentes na Europa, o IPP precisa do apoio dos diferentes atores envolvidos, governo, indústria e consumidor (CHARTER et al., 2001).

O IPP integra políticas de informação ao consumidor, emissões, resíduos, compras públicas sustentáveis, tributação verde, e produção e consumo sustentáveis.

As compras públicas respondem por boa parte do PIB dos países europeus, tornando-se uma valiosa oportunidade para a melhoria ambiental. A utilização de critérios ambientais e de sustentabilidade nas compras públicas tendem a estimular o mercado de produtos sustentáveis. A utilização da rotulagem ambiental contribui com esse modelo de compra, pois existe uma lacuna na prestação das informações por parte do fornecedor. A rotulagem pode, além de fornecer a informação desejada, garantir que ela ser verdadeira, tendo em vista o processo de certificação (CALABRO, 2007).

O IPP também está totalmente integrado com o plano de ação em produção e consumo sustentáveis, e a política de sustentabilidade industrial. Neste plano de ação, estão incluídas mudanças no padrão de design de produto, visando a melhor embalagem para o meio ambiente; mudança no padrão de consumo e rotulagem ambiental, capaz de contribuir com a escolha dos consumidores. Há ainda, a qualificação dos fornecedores das empresas fabricantes, garantindo um processo produtivo mais sustentável (EUROPEAN COMISSION, 2009).

Nas questões relacionadas a resíduos sólidos, um novo regulamento foi publicado na Europa em 2008, de maneira a considerar todo o ciclo de vida do produto nesta política. Assim, o descarte adequado passou a ser relacionado 
com o processo produtivo, de maneira a dar a destinação mais adequada para o produto pós-consumo. No caso das baterias, por exemplo, ao invés da reciclagem, após o uso o produto segue para a disposição adequada (EUROPEAN COMISSION, 2009).

A rotulagem ambiental tipo III é melhor adotada pelas empresas e melhor implementada quando integrada com outras políticas, já que ela pode ser considerada uma ferramenta para as demais políticas de sustentabilidade e um instrumento de geração de informação, tanto para as próprias empresas, como para a sociedade em geral. 


\section{A PROPOSTA DO SISTEMA BRASILEIRO DE DECLARAÇÃO AMBIENTAL DE PRODUTO E ROTULAGEM TIPO III}

A Declaração Ambiental de Produtos e a rotulagem tipo III deve ser considerada uma política de estímulo à sustentabilidade. Acredita-se que a adoção desta política poderia ser potencializada por outras políticas ambientais e sociais de estímulos à mudança no padrão de produção e consumo.

Neste capítulo serão abordados o histórico do sistema de Declaração Ambiental de Produto (DAP) e rotulagem ambiental tipo III, política de origem do Instituto Nacional de Metrologia, Qualidade e Tecnologia (INMETRO); a análise do sistema brasileiro proposto; o arcabouço institucional para tal aplicação e a integração da política de DAP com outras políticas de incentivo já existentes à sustentabilidade de produtos.

\subsection{Histórico do sistema de Declaração Ambiental de Produto no Brasil}

O histórico para a elaboração do sistema DAP no Brasil foi adquirido através de entrevista realizada com a Sra. Maria Aparecida Martinelli, coordenadora de projetos de conformidade, no INMETRO.

A implantação do sistema de Declaração Ambiental de Produtos (DAP) do país está sendo conduzido pelo Instituto Nacional de Metrologia, Qualidade e Tecnologia (INMETRO). O Instituto é uma autarquia federal, criada em 1973, vinculada ao Ministério do Desenvolvimento, Indústria e Comércio Exterior (MDIC), que executa políticas públicas definidas por um colegiado Interministerial, o Conselho Nacional de Metrologia, Normalização e Qualidade Industrial (CONMETRO). Ambos formam o Sistema Nacional de Metrologia, Normalização e Qualidade Industrial (SINMETRO).

Dentro da estrutura do INMETRO encontra-se a Diretoria de Avaliação da Conformidade, responsável pelos programas dessa área e pelo Programa Brasileiro de Avaliação do Ciclo de Vida (PBACV). 
Conselho Nacional de

Metrologia, Normalização

e Qualidade Industrial

(CONMETRO)

Metrologia, Normalização

e Qualidade Industrial (SINMETRO)
Instituto Nacional de

Metrologia, Qualidade e

Tecnologia (INMETRO)

Diretoria de Avaliação da

Conformidade (DICONF)

Figura 5: Sistema Nacional de Metrologia, Normalização e Qualidade Industrial (SINMETRO). Fonte: Autoria própria.

A política de declaração ambiental de produto no Brasil foi instituída através da Portaria INMETRO nำ 100, de 07 de março de 2016, e denominada Programa Voluntário de Rotulagem Ambiental Tipo III-Declaração Ambiental de Produto (DAP). Esta política é voluntária, permitindo uma adequação a longo prazo pelas empresas. A Portaria foi resultado de um processo que teve início em 2010, com o Programa Brasileiro de Avaliação do Ciclo de Vida (PBACV).

O PBACV originou-se da necessidade do envolvimento do setor privado nas discussões e elaboração de inventários de avaliação do ciclo de vida de produtos, que vinham sendo desenvolvidos pelo Instituto Brasileiro de Informação em Ciência e Tecnologia (IBICT). Por solicitação do IBICT o INMETRO foi chamado a fazer esta ponte com o setor privado, uma vez que é o instituto ligado ao Ministério de Desenvolvimento da Indústria e Comércio Exterior (MDIC), e através do CONMETRO estabeleceu dois regulamentos ${ }^{10}$ para a criação do PBACV, que trouxe, entre seus objetivos, o incentivo do uso da informação sobre impactos ambientais nas políticas públicas e melhoria do

\footnotetext{
10 Resolução CONMETRO oㅡ 03, de 12/05/2010: aprova o termo de referência para o Programa Brasileiro de Avaliação do Ciclo de Vida. Resolução CONMETRO no 04, de 15/12/2010: aprova o Programa Brasileiro de Avaliação do Ciclo de Vida.
} 
desempenho das empresas, a implantação de um sistema de inventários de ciclo de vida no país e a difusão e implementação da ACV no Brasil.

Foi a partir do estabelecimento do Programa Brasileiro de Avaliação do Ciclo de Vida que o CONMETRO delegou ao INMETRO a competência para tratar da rotulagem ambiental. Na Resolução CONMETRO nํ 04/2010, aparece como uma das ações do Programa o desenvolvimento de programas de rotulagem ambiental no âmbito do Sistema Brasileiro de Avaliação da Conformidade (SBAC).

Após dois anos da criação do Programa foi definido um Plano de Ação Quadrienal ${ }^{11}(2012$ - 2015), que através de projetos estratégicos definiu as ações para implementação da avaliação do ciclo de vida no Brasil. Um dos projetos estratégicos era o desenvolvimento de programa de avaliação de conformidade e rotulagem ambiental. Neste sentido, avaliou-se a possibilidade do INMETRO trabalhar uma política de implementação de rotulagem ambiental tipo I, já que esta estava sendo amplamente utilizada pelo setor privado. Após diversas análises de estudos internacionais e contato com a Academia, decidiuse que o ideal era o INMETRO trabalhar na rotulagem tipo III, que estava sendo trazida ao Brasil, através da Norma ISO 14025:2006 e já estava sendo adotada em diferentes países no mundo.

Com a definição de uma equipe interna da diretoria de avaliação de conformidade do INMETRO e o apoio da Academia, iniciou-se o trabalho de elaboração do Programa de DAP. A equipe foi capacitada, para ter os conhecimentos básicos necessários para a análise das referências consultadas e o regulamento foi elaborado de acordo com a experiência nos programas de avaliação da conformidade já existentes no Instituto.

Além de utilizar como base a Norma ISO 14025:2006, a equipe analisou os sistemas da Suécia e da Inglaterra. Após um ano de trabalho e diferentes textos elaborados, foi publicado um texto final como consulta pública ${ }^{12}$, em que se abriu a discussão para contribuições do setor privado e da sociedade em geral.

Vale destacar que o sistema brasileiro está baseado em referências internacionais, em sintonia com sistemas já existentes, permitindo um

11 Resolução CONMETRO no 01, de 16/05/2012: aprova o Plano de Ação Quadrienal do PBACV.

12 Consulta Pública através da Portaria ํำ110, de 25/02/2015. 
reconhecimento entre países. Ao ser trazida como uma política de governo, o sistema de DAP brasileiro direciona as empresas para uma metodologia única e mundialmente reconhecida, garantindo a construção dos bancos de dados do Brasil conforme os bancos de dados dos demais países, facilitando a "comunicação" comercial.

A consolidação das contribuições e a discussão com o setor privado durou onze meses. Durante estas discussões o setor privado apresentou suas preocupações em relação à política estabelecida pelo INMETRO, dentre elas a questão da confidencialidade dos dados do produto e a exigência de avaliação do ciclo de vida nas compras públicas sustentáveis, em curto prazo. Após a consolidação, o regulamento foi publicado e está em vigor desde então.

Após a publicação do texto que foi consulta pública, houve a demanda de um setor industrial (do cobre) para implementação do sistema DAP proposto pelo INMETRO. Este setor está participando de um projeto piloto, em que será aplicado o regulamento do INMETRO de DAP, avaliando-se as dificuldades para a elaboração da declaração ambiental de produto e a rotulagem tipo III. Esse projeto pode auxiliar na melhoria do regulamento. Caso seja necessário, o regulamento poderá sofrer alterações, conforme diagnóstico do projeto piloto.

\subsection{Políticas Públicas e Iniciativas: sintonia e integração com a Declaração Ambiental de Produtos}

Historicamente no mundo, as políticas de proteção ambiental baseiam-se no princípio da precaução e do poluidor-pagador, tornando-as políticas de comando e controle, dando ao Estado a responsabilidade de fiscalização e proteção do meio ambiente. Recentemente, tem-se observado em políticas ambientais o uso de um novo princípio, de protetor-recebedor, e o surgimento de uma nova maneira de pensar políticas ambientais, tornando-as menos de comando e controle e mais de incentivo, permitindo a adequação do próprio mercado, reduzindo as necessidades de fiscalização e transferindo a responsabilidade pela minimização dos impactos ambientais a toda a população.

Assim, altera-se a lógica de apenas punir o causador do dano, para a lógica de encorajar a adoção voluntária de medidas capazes de minimizar os 
prejuízos ao meio ambiente, alcançando, com a contribuição de todos, a sustentabilidade (SILVA, 2014). Políticas de estímulo tendem a ser benéficas por induzir a inovação tecnológica instigando empresas na busca por processos e produtos ambientalmente melhores e despertando no consumidor maior consciência quanto à sua compra (TAMANAHA, 2013).

O Programa Rotulagem Ambiental tipo III-DAP do INMETRO está na linha das políticas de incentivo e não de comando e controle. Primeiramente, por se tratar de uma política voluntária, em segundo lugar, por impulsionar a geração de dados e informações internamente na empresa, além de incitar a melhora dos processos produtivos e dos produtos. Ainda, o Programa dialoga com diversos outros regulamentos e políticas existentes no Brasil, sejam elas de comando e controle, sejam de incentivo.

Enumera-se neste trabalho as seguintes políticas capazes de serem integradas com a DAP: a) Política Nacional de Mudanças Climáticas; b) Política Nacional de Resíduos Sólidos; c) Compras Públicas Sustentáveis; d) Tributação ambiental; e, e) Políticas de estímulo à exportação. Estas políticas foram levantadas com base nas experiências internacionais, em que políticas desta natureza foram utilizadas como indutoras para o uso da DAP pelas empresas.

a) A Política Nacional de Mudança do Clima (PNMC) foi sancionada em 2009, sob a Lei 12.187, de 29/12/2009, e deu a todos, incluindo à população, a responsabilidade para garantir o desenvolvimento sustentável, a partir da redução das emissões dos gases do efeito estufa.

As discussões sobre mudanças climáticas despertaram o interesse nas rotulagens ambientais, por serem vistas como capazes de auxiliar os consumidores nas suas escolhas no momento do compra (HORNE, 2009).

Podem ser destacadas duas diretrizes da PNMC, que guardam alguma relação com o programa de DAP e rotulagem ambiental tipo III: o apoio e o fomento às atividades que reduzam a emissão de gases do efeito estufa (GEE) e a necessidade de mudança nos padrões de produção e consumo existentes hoje. Nos instrumentos, um deles chama a atenção, que é o estímulo ao desenvolvimento de processos e tecnologias capazes de reduzir os GEE (BRASIL, 2009). 
Diversas iniciativas no mundo foram tomadas com o objetivo de gerar informações sobre a cadeia de produção para o consumidor, visando a redução das emissões dos GEE (FINKBEINER, 2009). Essa seria uma maneira de direcionar o consumo para uma forma mais sustentável.

Para mudar o padrão de produção e consumo é essencial a informação do processo e do produto. Neste sentido, a PNMC pode contribuir com a adoção da DAP e da rotulagem ambiental tipo III e vice-versa. Com a necessidade de elaboração das regras de categoria de produtos (RCP) e da DAP as empresas coletarão informações relevantes sobre o processo e o ciclo de vida do produto, podendo alterar seu padrão de produção, diminuindo suas emissões de gases do efeito estufa e comunicando ao consumidor quanto aquele produto emite.

No caso do processo produtivo, a abordagem do ciclo de vida, necessária para a elaboração da DAP, faz com que os fabricantes tabulem informações relativas às emissões na fabricação de seus produtos, em alguns casos, desde a extração da matéria-prima até a disposição final (REBITZER et al., 2004).

A disponibilização das informações no rótulo pode auxiliar os consumidores na escolha do produto mais sustentável, aumentando o poder de decisão da população mais consciente.

b) A Política Nacional de Resíduos Sólidos - PNRS (Lei 12.305, de 02/08/2010) pode ser considerada uma das políticas mais diretamente relacionadas com a elaboração das RCP e da DAP. Visando a produção e o consumo sustentável, a redução e o tratamento de resíduos após o uso, a PNRS trouxe em seus objetivos ${ }^{13}$ o estímulo ao uso da Avaliação do Ciclo de Vida do produto e em seus princípios ${ }^{14} \mathrm{o}$ direito da sociedade à informação.

Nos últimos anos, com o aumento o consumo pela população no mundo, aumentou-se significativamente a geração de resíduos, buscando-se cada vez mais uma produção e um consumo consciente e sustentável. Por esta razão, a PNRS definiu que a responsabilidade pelo ciclo de vida do produto passa a ser de toda sociedade, cada elo com sua responsabilidade específica.

Nesse caso, a responsabilidade compartilhada não está relacionada apenas à logística reversa de produtos e embalagens, mas também ao 
fornecimento de informações pelo fabricante, importador ou distribuidor ao consumidor, visando a redução na geração de resíduos e a destinação ambientalmente adequada (JURAS; ARAÚJO, 2012).

De acordo com Queiroz \& Garcia (2007), tanto a ACV como a rotulagem ambiental são ferramentas essenciais para a gestão integrada dos resíduos sólidos e para se alcançar o desenvolvimento sustentável. Os autores ressaltam ainda que a rotulagem ambiental deve ser instituída através de uma política de governo, garantindo-se a veracidade das informações.

Ainda, pode-se utilizar a DAP para a escolha do melhor tratamento para o resíduo. Em estudo realizado por Binaghi et al (2007) o autor concluiu que o uso de DAP nos serviços de tratamento de resíduos permite a escolha da destinação mais adequada por parte dos municípios e empresas fabricantes de produtos, além de gerar mais informações para os consumidores.

Assim, a PNRS pode ser considerada uma política capaz de induzir a adoção do Programa brasileiro de rotulagem ambiental tipo III, dando ao consumidor as informações necessárias para a destinação correta dos resíduos (produtos e embalagens), ao mesmo tempo em que o Programa pode auxiliar as empresas nas questões de gestão de resíduos industrial e pós-consumo, contribuindo para a melhoria dos processos produtivos e da destinação correta de resíduos.

c) O processo de Compras Públicas Sustentáveis foi instituído no Brasil em 2010, por meio de instrução normativa ${ }^{15}$ do Ministério do Planejamento, fazendo com que os órgãos do poder Executivo deem preferência aos produtos e serviços sustentáveis no momento da aquisição. Após a publicação da instrução normativa outros ordenamentos jurídicos ${ }^{16}$ fortaleceram a iniciativa das compras públicas sustentáveis.

As compras governamentais têm papel de destaque no mercado, podendo direcioná-lo para uma produção sustentável e conduzir o consumidor, a partir do exemplo dado, para um consumo sustentável (LI \& GEISER, 2005).

As compras governamentais respondem por boa parte do Produto Interno Bruto (PIB) dos países, variando entre 8 e 25\% (BRAMMER et al., 2011). No

15 Instrução Normativa 01/2010.

16 Lei 12.349/2010. 
Brasil, as compras públicas são responsáveis por movimentar $10 \%$ do PIB, alcançando a ordem de $R \$ 45$ bilhões em 2015. Destes, 0,86\% referem-se às compras sustentáveis, o que vale a 930 processos de compra no ano (MINISTÉRIO DO PLANEJAMENTO, ORÇAMENTO E GESTÃO, 2015). Os dados mostram que as aquisições sustentáveis pelos órgãos de governo ainda são baixas, tendo espaço para crescimento.

Uma das dificuldades para os gestores na implementação das compras sustentáveis é a identificação de um produto sustentável e a outra é o estabelecimento dos requisitos que podem ser usados nos editais. Atualmente, não é possível exigir a certificação ou selos que possam comprovar as promessas dos fornecedores, ou os requisitos existentes nas normas ISO tornando baixa a adesão a esse processo. Isso devido a orientação do Tribunal de Contas da União (TCU) que entende que a exigência de requisitos de normas técnicas ou de selos específicos pode ser considerada uma forma de reserva de mercado (HOE, 2014).

A institucionalização da rotulagem tipo III, através de um programa governamental pode permitir a exigência nas compras públicas sustentáveis, por parte dos gestores públicos. Isso poderia garantir a confiabilidade da informação para os órgãos de governo, sendo um instrumento para distinguir os produtos mais sustentáveis.

Além das informações desse tipo de rotulagem serem provenientes do ciclo de vida do produto, permitindo que o gestor público enxergue os impactos causados no processo produtivo como um todo, os requisitos são bem definidos nas regras de categoria de produtos e as informações contidas nas declarações ambientais de produto disponibilizadas para os interessados. Isso permitiria o uso em editais, pelos gestores, de requisitos já estabelecidos e o reconhecimento do produto sustentável a partir do selo disponibilizado pelo INMETRO.

Além disto, conforme apontado anteriormente, a aplicação do sistema de DAP pode ser uma maneira de documentar evidências relacionadas aos requisitos legais ambientais e especificações técnicas dos produtos (BOGESKÄR et al., 2002). 
Por se tratar de uma informação certificada, a confiança na informação por parte do gestor público torna-se maior e tal como a adesão pelas empresas do programa de DAP.

Deve-se observar, que a legislação ${ }^{17}$ específica para licitações públicas define margens de preferência para micro e pequenas empresas. Assim, o programa de DAP deve garantir a participação das empresas nacionais, independente do porte. Uma mudança que poderia vir na lei de licitações (proposta de alteração já tramita na Câmara dos Deputados) é a inclusão de uma margem de preferência para produtos sustentáveis, fornecidos por micro e pequenas empresas, estimulando ainda mais a implementação do programa DAP pelas empresas nacionais.

As aquisições públicas sustentáveis podem funcionar como um instrumento essencial na integração de políticas de sustentabilidade, inclusive no que diz respeito ao programa de rotulagem ambiental tipo III (LI \& GEISER, 2005).

d) A discussão sobre a tributação ambiental no Brasil avança, mas o país ainda não consolidou este instrumento de uma maneira clara, como uma política de incentivo. Na verdade, não há uma política estabelecida e utiliza-se a própria legislação tributária e outros incentivos fiscais e econômicos, que tratam ou se relacionam de alguma forma às questões ambientais. Este tipo de política tende a ter alto impacto no mercado, dada sua abrangência e relevância nas questões econômicas (TAMANAHA, 2013).

O uso de incentivos econômicos na proteção do meio ambiente ganhou força na década de 80 , após diversos acidentes ambientais graves e a constatação de que apenas políticas de comando e controle não eram suficientes para impedir a deterioração ambiental. Os instrumentos econômicos podem estimular o controle dos impactos ambientais por meio da adoção de tecnologias que surgem no mercado, facilitando a desregulamentação e o controle por parte do Estado (GUIMARÃES, et al., 1995).

De acordo com Costa (2011, p. 332), tributação ambiental pode ser conceituada como "emprego de instrumentos tributários para gerar recursos

\footnotetext{
17 Lei 8.666/1991.
} 
necessários à prestação de serviços públicos de natureza ambiental, bem como para orientar o comportamento dos contribuintes à proteção do meio ambiente." Ainda segundo a autora, é possível utilizar-se de isenção e deduções, além da redução progressiva de impostos e taxas, para se alcançar os benefícios ambientais almejados.

Assim, a tributação ambiental pode contribuir com a implementação da DAP e da rotulagem tipo III, a partir do momento em que se utilizar as informações geradas por esse sistema para o controle do pagamento ou isenção de tributos e taxas. Além disto, este tipo de incentivo poderia compensar as despesas com a verificação e certificação da DAP, exigidas no Programa. A isenção tributária, fiscal ou de taxas estimulará a adoção das empresas ao Programa Brasileiro de DAP. Provavelmente será neste momento que empresas de mercado nacional terão interesse em aplicar a DAP e a rotulagem tipo III aos seus produtos.

e) As políticas de exportação podem estimular as empresas exportadoras na adoção do Programa do INMETRO, uma vez que há exigências internacionais de certificação de produtos e rotulagem ambiental tipo III em diversos países do mundo.

Utilizando como exemplo o setor de cosméticos, em dez anos (2004 a 2014) o setor obteve, em média, um aumento de $7,5 \%$ nas exportações de produtos, chegando em 2014 a exportar US $\$ 798$ milhões. São 134 países de destino das exportações brasileiras. Este aumento pode ser resultado do programa de internacionalização dos produtos brasileiros, desenvolvido pelo setor, em parceria com órgãos governamentais (ABIHPEC, 2015).

Ao entrevistar o representante da Confederação Nacional da Indústria (CNI), ficou claro que as empresas que primeiro irão aderir à política do INMETRO são as empresas exportadoras, que precisam cumprir com exigências ambientais internacionais.

O estímulo de políticas de desenvolvimento da indústria nacional voltada para a exportação tende a impulsionar o Programa Rotulagem Ambiental tipo IIIDAP, já que alguns países, como os europeus, estão exigindo esta certificação e outros veem com bons olhos a existência destas informações para 0 consumidor. 
A integração de políticas de sustentabilidade é possível, apesar das dificuldades que podem ser encontradas. A integração completa dessas políticas depende de fatores, como institucionalização das iniciativas, estrutura organizacional, comunicação e disseminação de informações ambientais verdadeiras, credibilidade e veracidade das informações fornecidas pelos fabricantes e disponibilidade dos atores em contribuir com as mudanças necessárias (LI \& GEISER, 2005).

\subsection{O sistema Brasileiro de Declaração Ambiental de Produtos e os sistemas no Mundo}

Dada a tendência de se obter o reconhecimento mútuo entre os sistemas de rotulagem tipo III dos diferentes países, se faz necessário entender se o sistema brasileiro proposto pelo INMETRO estaria já alinhado, facilitando esse reconhecimento.

Foi feita análise comparando o sistema brasileiro, descrito anteriormente, com os sistemas apresentados no capítulo 2. Para uma análise mais profunda foi utilizada como referência o sistema operado pela International EPD System, uma vez que é a organização que congrega maior número de sistemas, de diferentes países.

De modo geral, não há muitas diferenças entre os sistemas analisados, uma vez que todos devem seguir a norma ISO 14025. Isto permite a padronização no fluxo da geração da Declaração Ambiental de Produtos.

Uma das diferenças encontradas no sistema brasileiro, em comparação com os demais sistemas, foi a obrigatoriedade de consulta pública das Regras de Categorias de Produtos (RCP) elaboradas pelo Comitê Técnico. Este é um ponto positivo, já que garante a transparência no processo e a participação de todos os interessados. No International EPD System a transparência é dada por um fórum aberto que permite a participação dos stakeholders e pela possibilidade de comentários ao documento elaborado pelo comitê de RCP, o que seria similar à consulta pública brasileira. 
Outra diferença identificada entre os diversos sistemas dos diferentes países foi a origem da política de rotulagem e sua obrigatoriedade ou não. $\mathrm{Na}$ grande maioria dos países os programas são voluntários e outras políticas de sustentabilidade estimularam sua adoção. Na Europa, o programa tornou-se obrigatório, por fazer parte da política de consumo sustentável, além de integrarse no mercado único. No Brasil, o programa ainda é voluntário, embrionário e pode ser integrado às demais políticas ambientais existentes hoje.

Em relação à origem, o sistema brasileiro surgiu no poder público, já em outros países, o sistema é misto ou de origem privada. A Tabela 1 apresenta algumas características dos programas analisados neste trabalho.

Ao se comparar o regulamento do INMETRO (Portaria 100/2016) com o documento de instruções do programa do International EPD System (2015), observa-se o amadurecimento do sistema nascido na Suécia. Muitos pontos do operador europeu são relevantes para garantir a harmonização dos diversos sistemas congregados por este operador.

O International EPD System permite ao solicitante a possibilidade de realizar a uma pré-verificação da DAP no momento de elaboração da RCP. De acordo com o sistema, esta pré-verificação pode contribuir com as discussões da elaboração da RCP, esclarecendo eventuais dúvidas que o processo de certificação poderia levantar. Isto não está previsto na política brasileira e, para ser colocada em prática, um dos pontos que teria que ser avaliado é a questão do custo. Se este procedimento representar um incremento no custo da rotulagem tipo III, dificilmente as empresas nacionais estariam dispostas a fazêlo.

Um dos pontos observados no documento de referência do International EPD System é a existência de um anexo que define as informações necessárias para o estudo de ACV. Este tipo de informação pode auxiliar na homogeneidade das RCP elaboradas. 
Tabela 1: Comparação entre os programas de DAP.

\begin{tabular}{|c|c|c|c|c|}
\hline \multicolumn{5}{|c|}{ PAÍSES COM SISTEMA DE ROTULAGEM BASEADO NA DECLARAÇÃO AMBIENTAL DE PRODUTOS } \\
\hline PAÍS & PROGRAMA & INICIATIVA & GARANTIA DA INFORMAÇÃO & $\begin{array}{l}\text { INTEGRAÇÃO COM } \\
\text { OUTRAS POLÍTICAS }\end{array}$ \\
\hline Alemanha & AUB, UBA & Privada & & Sim \\
\hline Brasil & Rotulagem Ambiental Tipo III - DAP & Governamental & Verificado por 3a parte & Não \\
\hline Canadá & EPDS & Privada & $\begin{array}{c}\text { Verificado por } 3^{\mathrm{a}} \text { parte a } \\
\text { ACV e a DAP }\end{array}$ & Não \\
\hline China & Não Identificado & Governamental & Verificação por 3a parte & Sim \\
\hline Coréia do Sul & Programa Rotulagem Tipo III & Governamental & Certificação por 3a parte & Sim \\
\hline Estados Unidos & Diversos & Privada & Verificação por 3a parte & Sim \\
\hline França & $\mathrm{NF}$ & Governamental & Verificação por 3a parte & Sim \\
\hline Índia & Eco Mark & Governamental & $\begin{array}{c}\text { Verificado e certificado por } \\
\text { 3a parte a DAP }\end{array}$ & Sim \\
\hline Japão & JEMAI & Governamental & $\begin{array}{l}\text { Certificado por 3a parte a } \\
\text { informação da empresa (do } \\
\text { sistema de gestão) }\end{array}$ & Sim \\
\hline Suécia & Programa EPD & Parceria governo/privado & $\begin{array}{c}\text { Verificado e certificado por } \\
\text { за parte a ACV e DAP }\end{array}$ & Sim \\
\hline
\end{tabular}

Fonte: Autoria própria.

O programa brasileiro está bastante semelhante aos demais programas existentes no mundo. É preciso considerar que todos os programas seguem a norma ISO 14025, o que tende a manter a harmonização. As principais diferenças são encontradas nas regras de categorias de produtos elaboradas por cada país. Assim, em um segundo momento, após a implementação total da política no Brasil, poderá ser possível comparar, para um mesmo setor ou produto, uma RCP elaborada no país, com outra de outra origem.

\subsection{O sistema brasileiro de Declaração Ambiental de Produto}

Como apresentado anteriormente, o sistema de DAP no Brasil está sendo operado pelo INMETRO, através da Diretoria de Avaliação da Conformidade, e foi instituído a partir da Portaria 100/2016, sendo um programa ainda voluntário, para ser implementado pelas empresas em longo prazo. Apesar do regulamento atual não ser auto aplicável, ele define regras gerais e o funcionamento do sistema de DAP no país. $\mathrm{O}$ andamento do Programa e a elaboração de requisitos específicos dependerá da demanda setorial, ou de produto, pelos interessados. A aplicabilidade dessa política apenas ocorrerá com a elaboração dos requisitos 
específicos para cada setor produtivo ou produto nas Regras de Categorias de Produtos (RCP).

A partir desta demanda inicia-se o processo para se alcançar o selo do Programa de Rotulagem Ambiental Tipo III-DAP. Aqui será descrito o formato deste sistema, a partir da análise do regulamento. A figura 06 apresenta, em um fluxo, as etapas do sistema brasileiro de DAP.

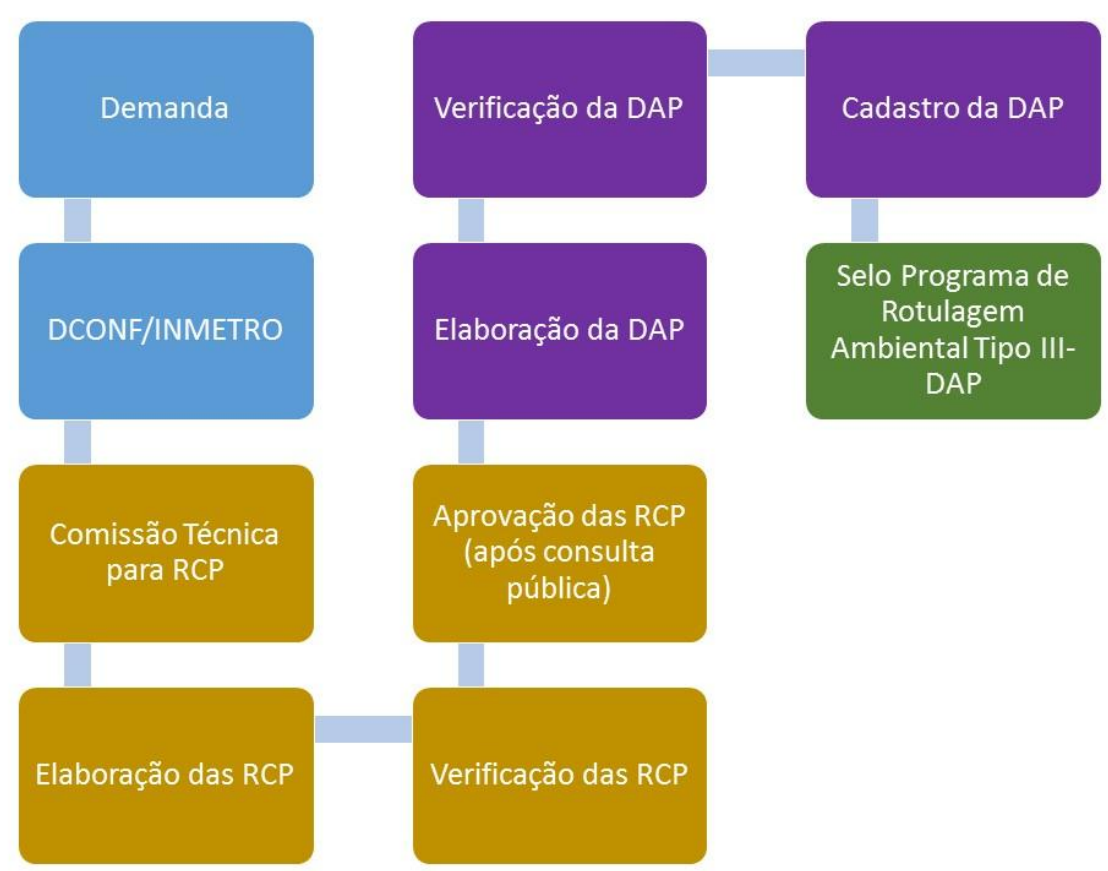

Figura 6: Sistema brasileiro de DAP. Fonte: Autoria própria.

A elaboração da DAP depende de requisitos específicos estabelecidos previamente nas Regras de Categorias de Produtos (RCP). As RCP são, de maneira geral, documentos que trazem as informações sobre o processo de fabricação, informações de impacto que deverão constar nas DAP, metodologias de cálculos e análise, informações de substâncias que compõem os produtos e formato e conteúdo da DAP.

No sistema brasileiro, as RCP são desenvolvidas ou avaliadas (se trazidas de outros programas existentes) por uma comissão técnica, de caráter consultivo, instituída pelo INMETRO e formada por representantes de entidades interessadas no produto em questão, especialistas, órgãos de governo e, caso seja um produto destinado ao consumidor, representantes dos consumidores. 
O conteúdo técnico mínimo das RCP, de acordo com o Programa de Rotulagem Ambiental Tipo III-DAP (Portaria 100/2016) inclui:

$>$ Definição e descrição da categoria do produto, com suas características básicas, função, uso e desempenho técnico;

$>$ Informações referentes aos processos de fabricação, uso e fim de vida;

$>$ Resultado da análise do inventário de avaliação de ciclo de vida, com dados e metodologias de cálculos do fluxo de materiais utilizados na produção e seus resíduos gerados;

$>$ Categorias de impactos ambientais relevantes e as regras de cálculo para estes impactos, com os limites de corte;

> Declaração de substâncias e materiais relevantes, dentre eles, os prejudiciais (pode-se utilizar regulamentos do país para definir a relevância da declaração de conteúdo).

Por conta da especificidade de seu conteúdo é que as RCP devem ser elaboradas ou avaliadas por uma comissão formada por especialistas e representantes dos setores específicos. A multidisciplinaridade da comissão auxiliará na análise das informações e na clareza do documento.

Após a elaboração, as Regras de Categoria de Produtos (RCP) devem ser revisadas por terceira parte, através de um painel de verificação, formado por pelo menos três membros, os quais não podem ser parte integrante da comissão técnica. Esta verificação gera um relatório, disponível a qualquer interessado, que apresenta a posição dos membros da comissão técnica em relação as $\mathrm{RCP}$ elaboradas, a transparência no processo de elaboração do documento, a presença ou não das informações essenciais sobre o produto (incluindo impacto) e a análise dos aspectos contidos. O regulamento do INMETRO traz em detalhes os pontos que devem ser avaliados na verificação.

Ao ser aprovada a RCP passa a fazer parte de uma lista específica publicada pelo INMETRO, aberta para consulta de qualquer interessado.

Tendo os requisitos obrigatórios definidos na RCP, a organização pode elaborar a Declaração Ambiental do Produto (DAP). A figura 7 apresenta em um fluxo as etapas do processo de elaboração da Declaração. A DAP pode ser setorial ou individual (por empresa), e neste último caso, se a empresa tiver diversas DAP pode ser feita uma certificação do processo de emissão de Declarações ao invés da certificação de cada DAP elaborada. Ainda, pode ser 
elaborada uma DAP abordando um impacto específico do produto, denominado no Programa DAP monotemática. Neste caso, o documento é adaptado da DAP completa e deve conter um aviso ressaltando que outros impactos do produto não foram avaliados.

De acordo com a Portaria do INMETRO, a DAP deve apresentar obrigatoriamente o seguinte conteúdo:

$>$ Informações do Programa, com dados que permitam a localização da DAP no INMETRO, validade do documento e escopo geográfico da Declaração;

> Informações sobre o produto, incluindo marca, características, uso, descrição técnica, conteúdo relevante e informações resumidas baseadas na $A C V$;

> Conteúdo do produto, pelo menos com as substâncias e materiais relevantes, com suas quantidades, porcentagem de reciclado utilizado, uso de renováveis e não renováveis, entre outras informações definidas na RCP;

> Desempenho ambiental (informações ambientais adicionais), baseadas na ACV do produto, não esquecendo de abordar os impactos ambientais mapeados.

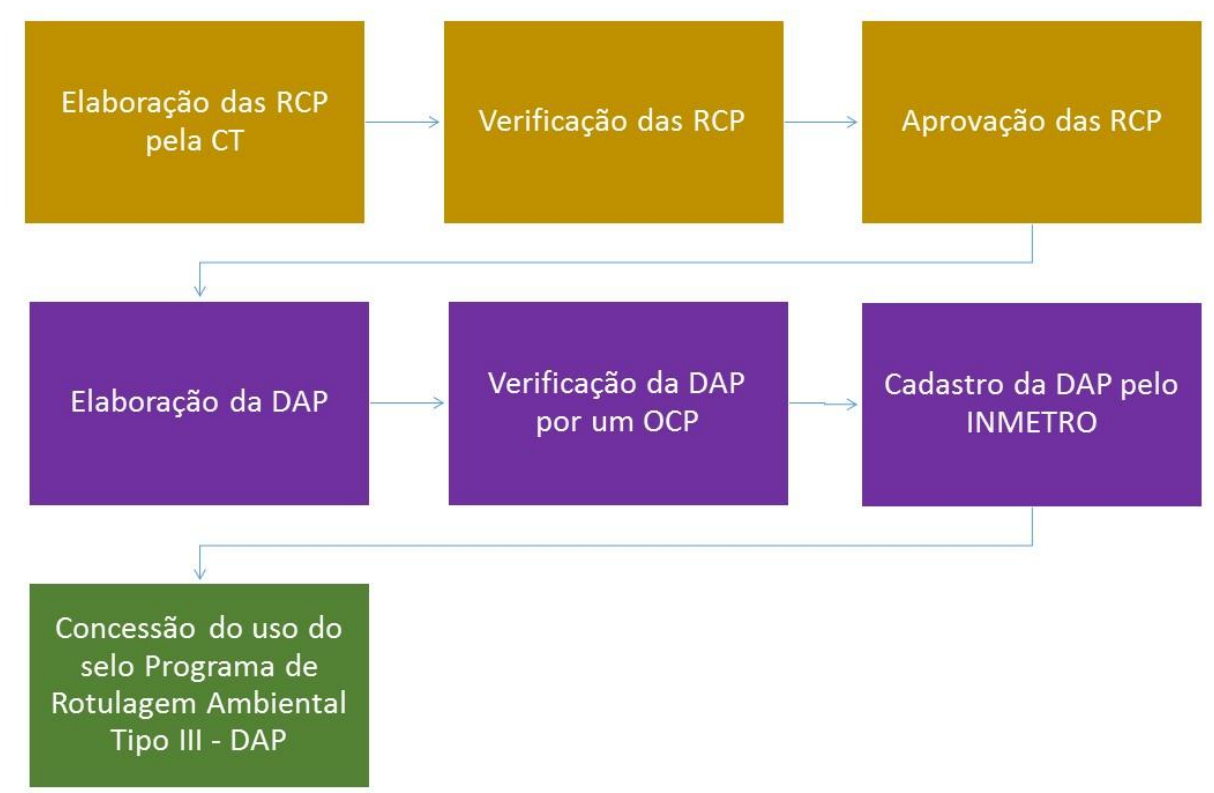

Figura 7: Fluxograma das etapas de elaboração de Declaração Ambiental de Produto (DAP). Fonte: Autoria própria. 
Após sua elaboração a DAP deve ser submetida à verificação por um Organismo Certificador de Produto (OCP), reconhecido pelo INMETRO. O conteúdo de uma DAP deve ser sempre verificável, uma vez que as informações que constam em uma rotulagem ambiental tipo III devem ser auditadas.

O processo de verificação da DAP pela OCP consiste em duas fases, uma de revisão documental e outra de validação. Na primeira, analisa-se todos os documentos fornecedores das informações e dados utilizados na elaboração da Declaração, garantindo que os inventários de avaliação do ciclo de vida utilizados estão de acordo com a RCP específica. Já na etapa de validação ocorre a avaliação da exatidão das informações da ACV e DAP e o processo de atualização destas informações; o processo de validação pode ser feito por amostragem e para os aspectos com maior influência nos resultados. No processo de verificação pela OCP também deve ser observada se a Declaração foi elaborada conforme os requisitos previstos na RCP específica.

A DAP aprovada é cadastrada pelo INMETRO, operador do sistema no Brasil, tornando-se disponível para consulta do público em geral. Esta declaração tem validade de três anos, devendo ser avaliada anualmente pela organização autora, visando a manutenção da veracidade das informações, conforme processos internos de fabricação dos produtos. Caso ocorra alguma mudança significativa, esta deve ser submetida à verificação da OCP e comunicada ao INMETRO, que publicará nova DAP, disponibilizando ao público sempre a versão mais atual. Pequenas alterações podem ser realizadas sem a necessidade de uma nova verificação de terceira parte, neste caso a empresa deve apenas comunicar ao operador do sistema a alteração realizada.

O sistema brasileiro de DAP, apesar de estar bem estruturado e em harmonia com os sistemas internacionais, apresenta algumas fragilidades $e$ oportunidades para o avanço na questão da rotulagem ambiental no Brasil. Com base na metodologia de análise SWOT foi possível analisar as forças, fraquezas, ameaças e oportunidades desta nova política pública. Como dito no item Metodologia, as forças e fraquezas são aspectos internos, aqui especificamente, intrínsecos do regulamento, enquanto as ameaças e oportunidades pertencem ao ambiente externo, neste caso, os interessados no regulamento.

A Figura 8 traz a matriz da análise SWOT elaborada para o regulamento publicado pelo INMETRO. 


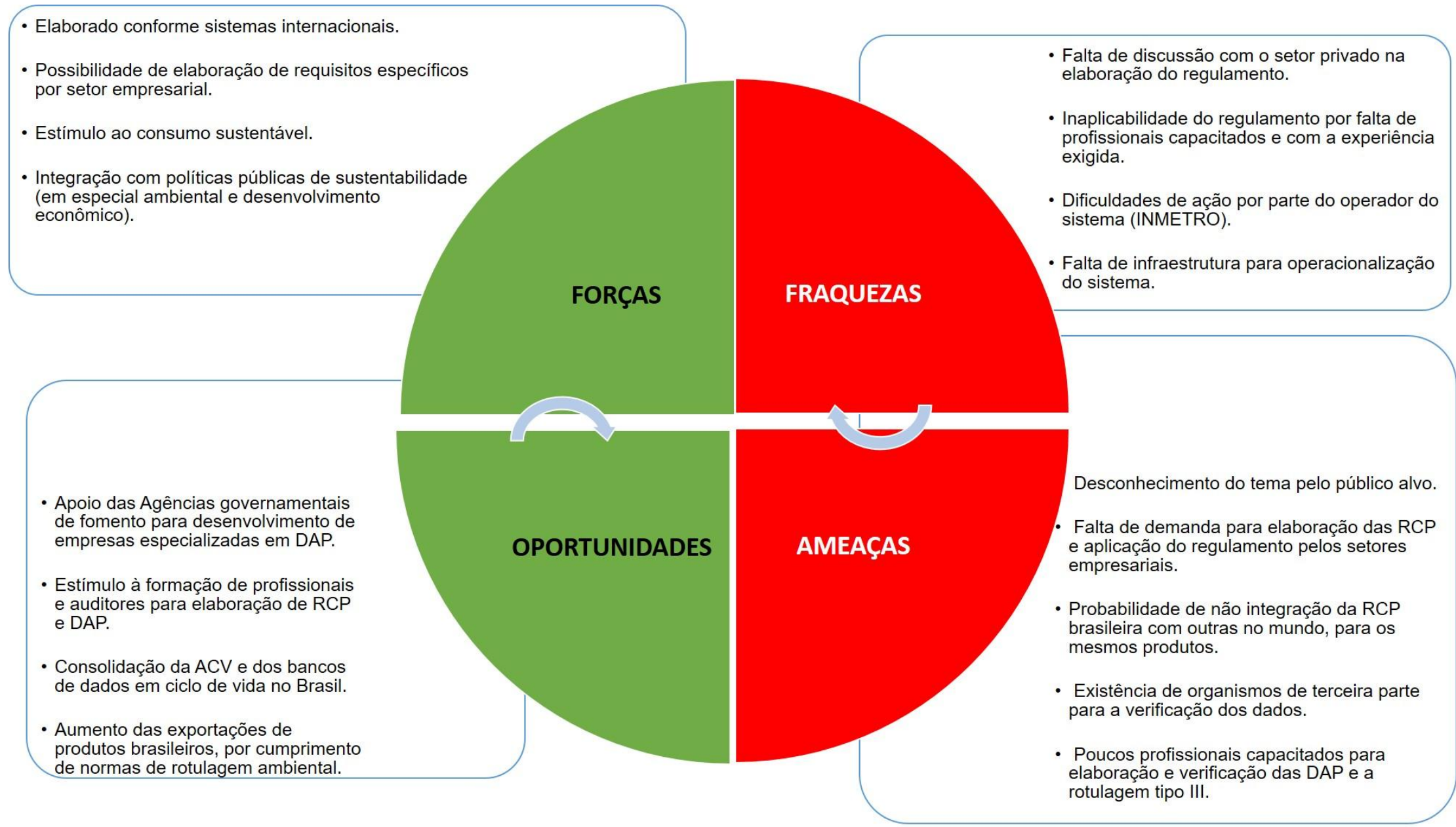

Figura 8: Análise SWOT do Programa DAP brasileiro. Fonte: Autoria própria. 
Elencado como força, a elaboração do regulamento harmonizado com sistemas internacionais permite a adequação da rotulagem dos produtos para a competição da indústria nacional no mercado externo. Além disso, garante ao sistema a entrada em banco de dados internacionais e a troca de informações com outros países. Pode também ser uma maneira de reduzir custos, já que possibilita o maior uso de RCP já existentes.

A abertura para que se tenha requisitos específicos por setor pode ser uma maneira de encorajar a adoção da política pública pelas empresas, por permitir que os interessados participem das discussões técnicas e apresentem seu conhecimento específico no produto ou setor. Este tipo de participação costuma tranquilizar o setor privado por garantir que o regulamento seja factível e aplicável ao negócio em questão.

Por se tratar de um regulamento relacionado a rotulagem de produtos (empresa - consumidor ou empresa - empresa) esta política deve ser considerada uma política de estímulo ao consumo sustentável, pois pode auxiliar o consumidor na sua escolha no momento da compra e auxiliar as empresas na seleção de seus fornecedores. A questão relacionada ao consumidor exige maior amadurecimento da política e da população brasileira, que ainda não atingiu o nível necessário para o entendimento dos dizeres de rotulagem dos produtos.

Outro ponto de força identificado na análise foi a possibilidade de integração, a longo prazo, do Programa de Rotulagem Ambiental Tipo III-DAP com outras políticas de sustentabilidade, tais como as compras públicas sustentáveis e a tributação verde.

Quatro pontos de Fraquezas foram identificados no regulamento, a falta de discussão com o setor privado na concepção do documento; a probabilidade de inaplicabilidade da norma por falta de profissionais capacitados, o encontro de dificuldades na execução das ações por parte do INMETRO e a falta de infraestrutura para que o sistema opere.

A falta de uma conversa inicial com o setor privado pode gerar resistência na adesão ao regulamento, uma vez que este é voluntário. Ao mesmo tempo, se houvesse discussões prévias, é bem provável que o regulamento não fosse publicado, dada a necessidade de amadurecimento do empresariado brasileiro. 
Portanto, esta fraqueza, apesar de ter sido enumerada nas entrevistas, não deve interferir na implementação da política.

Uma das exigências encontrada na norma do INMETRO é a dos profissionais do Organismo de Certificação de Produto (OCP) ter experiência mínima de dois anos em identificação de aspectos ambientais, processo produtivo, metodologias de ACV e em assuntos regulatórios. Isto pode ser considerado um gargalo, pois pode não haver profissionais suficientes para atender a demanda gerada, paralisando o processo de cadastro das DAP pelo operador.

Foi também definida como uma fraqueza, as dificuldades que podem ser encontradas pelo INMETRO no momento de operacionalizar o sistema, já que será preciso uma equipe capacitada para a participação nas comissões técnicas de elaboração das RCP e para avaliação das DAP auditadas pelas OCP.

Relacionado ao anterior está o último ponto mapeado como fraqueza, a inexistência de infraestrutura para a operacionalização do sistema. Atualmente, não há organismos acreditados pelo INMETRO para verificação da DAP, porém entende-se que a demanda pela acreditação somente ocorrerá quando se iniciar a implantação do Programa pelas empresas. Além da falta de OCP não há ainda um sistema próprio do INMETRO para receber e dar publicidade as RCP e as DAP, mas este sistema pode ser adaptado a partir de outros sistemas de avaliação da conformidade já existentes.

Um dos problemas identificados nos programas de DAP existentes no mundo é a duplicação de regras de categorias de produtos. Podem existir diferentes RCP para o mesmo produto, resultando em diferentes informações para a rotulagem ambiental, caso o sistema não esteja centrado em um operador ou haja dificuldades na divulgação das regras elaboradas (MINKOV et al., 2015). Por esta razão, a operacionalização do programa pelo INMETRO deve ser muito bem implementada, minimizando as chances das duplicações e inconsistências ocorrerem.

No ambiente externo, para o público alvo, foram mapeadas oportunidades e ameaças. No caso específico deste trabalho, o público alvo determinado foram as empresas e o próprio governo (outros órgãos, diferentes do operador do sistema), que devem aplicar o regulamento. 
As oportunidades encontradas foram: apoio das agências de desenvolvimento para criação de empresas especializadas em DAP; estímulo à formação de profissionais e auditores para elaboração de RCP e DAP; consolidação da ACV e dos bancos de dados no Brasil; e, aumento das exportações de produtos brasileiros aos países que já exigem a rotulagem ambiental tipo III.

As Agências de fomento ao desenvolvimento, tais como $\operatorname{SEBRAE}^{18} \mathrm{e}$ $A B D I^{19}$, podem colaborar com o nascimento de empresas especializadas em elaborar as declarações ambientais de produto. Essas Agências podem financiar a capacitação de profissionais, a formalização de empresas e a estruturação para acreditação das empresas no INMETRO. A nova política de rotulagem ambiental tipo III pode ainda estimular a formação de profissionais e auditores necessários para a implementação da política, por serem os responsáveis por elaborar e verificar as Regras de Categorias de Produtos (RCP) e DAP.

A terceira oportunidade mapeada é a consolidação da Análise do Ciclo de Vida (ACV) no país e do banco de dados nacionais, elaborados a partir de dados gerados no Brasil ou nacionalizados. Os bancos de dados nacionais começaram a ser criados em 2001, no projeto do IBICT, mas após dezesseis anos ainda não estão consolidados e são pouco utilizados pelas empresas. Assim, a política de rotulagem ambiental tipo III, que necessita de informações advindas da ACV pode ser um estímulo ao melhoramento e utilização deste banco de dados.

Ao entrevistar o representante das indústrias (Confederação Nacional das Indústrias - $\mathrm{CNI}$ ), uma das oportunidades para o setor industrial é o aumento das exportações para países que exigem a rotulagem ambiental tipo III. Por estar alinhado com as metodologias internacionais, o Programa Rotulagem Ambiental Tipo III-DAP pode facilitar a aceitação da verificação e do selo nacional, reduzindo custos para as empresas exportadoras.

As ameaças mapeadas foram quatro. $O$ desconhecimento do tema pelo público alvo, foi elencado na entrevista com a CNI. O que pode ser observado é que falta conhecimento sobre DAP por parte dos empresários e esse desconhecimento pode ser considerado uma ameaça, pois pode criar resistência na implementação da política e na geração de demanda de elaboração de RCP.

18 SEBRAE: Serviço Brasileiro de Apoio às Micro e Pequenas Empresas.

19 ABDI: Agência Brasileira de Desenvolvimento Industrial 
A falta de demanda também pode ser considerada uma ameaça, porém, a tendência é que empresas exportadoras solicitem ao INMETRO a elaboração das RCP.

Como dito anteriormente, a inexistência de estrutura para a aplicação do regulamento pode ser um problema na implementação da política. Neste caso, a falta de organismos de terceira parte disponíveis para a verificação das RCP e DAP podem se tornar uma ameaça, pois aumentam as chances de morosidade do sistema (já que as empresas terão que aguardar a acreditação de OCP para a partir daí solicitarem a verificação), aumento do valor cobrado para a verificação e a desistência pelo uso do Programa. Isto somente não acontecerá se houver uma estruturação prévia a implementação.

Por se tratar de um regulamento extremamente recente não há ainda muitos profissionais capazes de atender as exigências descritas para a elaboração e verificação da DAP e rotulagem ambiental tipo III. Isto pode ser um problema no momento de formação da comissão técnica para elaboração dos requisitos específicos dos produtos, para a OCP, que não terá profissionais capacitados para contratação e para o setor empresarial. 


\section{ESTUdO DE CASO: A ROTULAGEM AMBIENTAL NO SETOR DE PRODUTOS DE HIGIENE PESSOAL E COSMÉTICOS E A RELAÇÃO COM O CONSUMO SUSTENTÁVEL}

Para este estudo de caso, foi selecionada a empresa Natura Cosméticos, tendo em vista que suas iniciativas ambientais fazem parte da essência e cultura da empresa. Além disso, a Natura já possui análise de ciclo de vida para seus produtos e uma tabela ambiental disponibilizada no rótulo para os consumidores.

Outro ponto importante para a escolha da empresa entrevistada está na relevância do setor de produtos cosméticos e de higiene pessoal no Brasil.

Para complementar a análise da aplicabilidade das Declarações Ambientais de Produtos foi entrevistada a Associação PROCOBRE, uma das primeiras no Brasil a elaborar uma DAP.

A maior parte das informações apresentadas neste capítulo foram adquiridas através das entrevistas realizadas.

O setor de higiene pessoal e cosméticos (HPC) tem se diferenciado dos demais setores industriais nos últimos anos. Enquanto a maioria dos setores da indústria vem sofrendo com a queda no faturamento e no volume, a indústria de cosméticos e higiene pessoal tem apresentado crescimento.

Composta por 2.540 empresas no Brasil, o setor de HPC é caracterizado por maioria de micro e pequenas empresas, tendo, deste total, apenas 20 grandes empresas. Nos últimos dezenove anos, a indústria de HPC apresentou um crescimento, deflacionado, de cerca de $10 \%$, garantindo um faturamento em 2014 de $\mathrm{R} \$ 43,2$ bilhões. Com foco nos mercados da América Latina e América do Norte, o mercado de HPC viu aumentar as suas exportações, em média, 8,8\% nos últimos dez anos, atingindo um faturamento de, aproximadamente, US $\$ 800$ milhões. O Brasil é o terceiro país no mundo em participação de consumo de HPC, refletindo a preocupação do brasileiro com o cuidado pessoal e o bemestar, além do aumento de renda no país, permitindo o consumo de mais pessoas das classes mais baixas (ABIHPEC, 2015).

\subsection{O caso da Natura S/A}


A Natura S/A é uma empresa nacional, de grande porte, que tem seu centro de Pesquisa e Desenvolvimento e fabricação de produtos cosméticos, perfumaria e produtos de higiene pessoal, localizada no interior de São Paulo (Cajamar), uma linha produtiva e de pesquisa no Pará, e centros de distribuições em São Paulo, Minas Gerais, Pernambuco e Rio Grande do Sul. Tem atuação mundial, com atividades na América Latina e Europa (NAKAHIRA \& MEDEIROS, 2009).

A atuação global da Natura já representa $30 \%$ dos resultados da empresa, tendo um crescimento de $47 \%$ ao longo de cinco anos. Há produção local própria no México, Colômbia e Argentina, além da utilização de terceiros na França, Peru e Chile. Na França, o modelo de vendas utilizado pela empresa auxilia na captação de tendências e adaptação ao mercado internacional (NATURA, 2016). Desde 2004 a empresa possui ações na Bolsa de Valores e, reforçando sua cultura em sustentabilidade, desde 2006 as ações da Natura figuram no Índice de Sustentabilidade Empresarial - ISE ${ }^{20}$ (BOVESPA, 2016).

Recentemente, a Natura foi certificada como empresa B Corp, sendo a maior empresa mundial e a única na América Latina de capital aberto certificada dentro deste movimento. O B Corp é um movimento mundial, que teve início em 2006, nos Estados Unidos, tornando-se global e reconhecendo empresas e organizações em todo mundo, que têm como objetivo um crescimento socioambiental e econômico de maneira justo, a partir de produtos, práticas e lucro. Com a certificação a missão socioambiental da Natura passa a figurar no estatuto da empresa e, com a renovação a cada dois anos da certificação, a empresa deverá ter novas práticas sempre (NATURA, [s.d.]).

As iniciativas da Natura em Sustentabilidade passam pelos três pilares fundamentais: social, econômico e ambiental, e ainda leva em consideração as questões culturais. Tendo como base esses pilares da sustentabilidade, a Natura apresenta algumas iniciativas, como carbono neutro, geração de renda, pagamento justo pela extração de matérias-primas da biodiversidade e consumo sustentável (NATURA, 2015). A rotulagem ambiental nos produtos Natura estão

\footnotetext{
20 ISE: esse Índice pode ser definido como uma ferramenta de análise comparativa das empresas listadas na Bolsa de Valores de SP (BOVESPA), sob o aspecto de sustentabilidade corporativa. A gestão técnica do Índice é realizada pela própria BOVESPA, enquanto a metodologia de avaliação dos indicadores das empresas é de responsabilidade do Centro de Estudos em Sustentabilidade da Faculdade Getúlio Vargas - GVCes (BOVESPA, [s.d.]).
} 
intimamente relacionados a esse último, assim como a disponibilidade de refil, para boa parte dos produtos da empresa, visando a minimização da geração de resíduos sólidos pós-consumo.

A tabela ambiental da Natura existe desde 2007, e é uma iniciativa voluntária da empresa. A iniciativa segue a proposta de informação ao consumidor da tabela nutricional e o objetivo no momento de sua criação era fornecer informações aos consumidores. Por se tratar de uma iniciativa voluntária e sem padrões definidos no mercado, a empresa estabeleceu seus critérios e desenvolveu a tabela ambiental baseada nestes. São seis critérios utilizados, sendo três para questões relacionadas ao produto e três para embalagens.
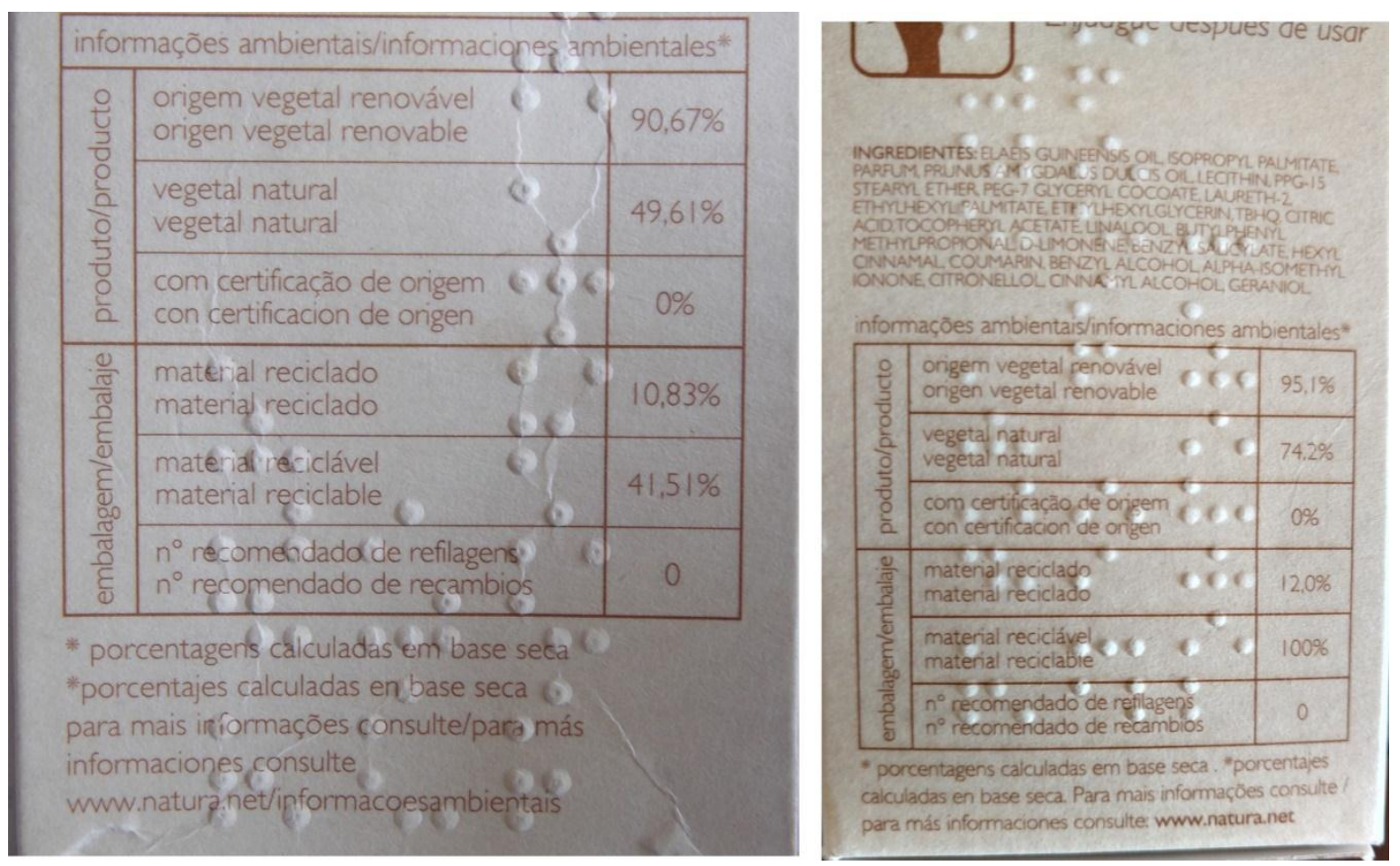

Figura 9: Rótulo Ambiental da Natura, para dois óleos corporais.

Em embalagem os três critérios avaliados pela empresa, presentes na tabela ambiental, são: número de vezes para a reutilização (se é refil ou não); se o material da embalagem é reciclável ou não; e, quanto da embalagem é composta de material reciclado. 


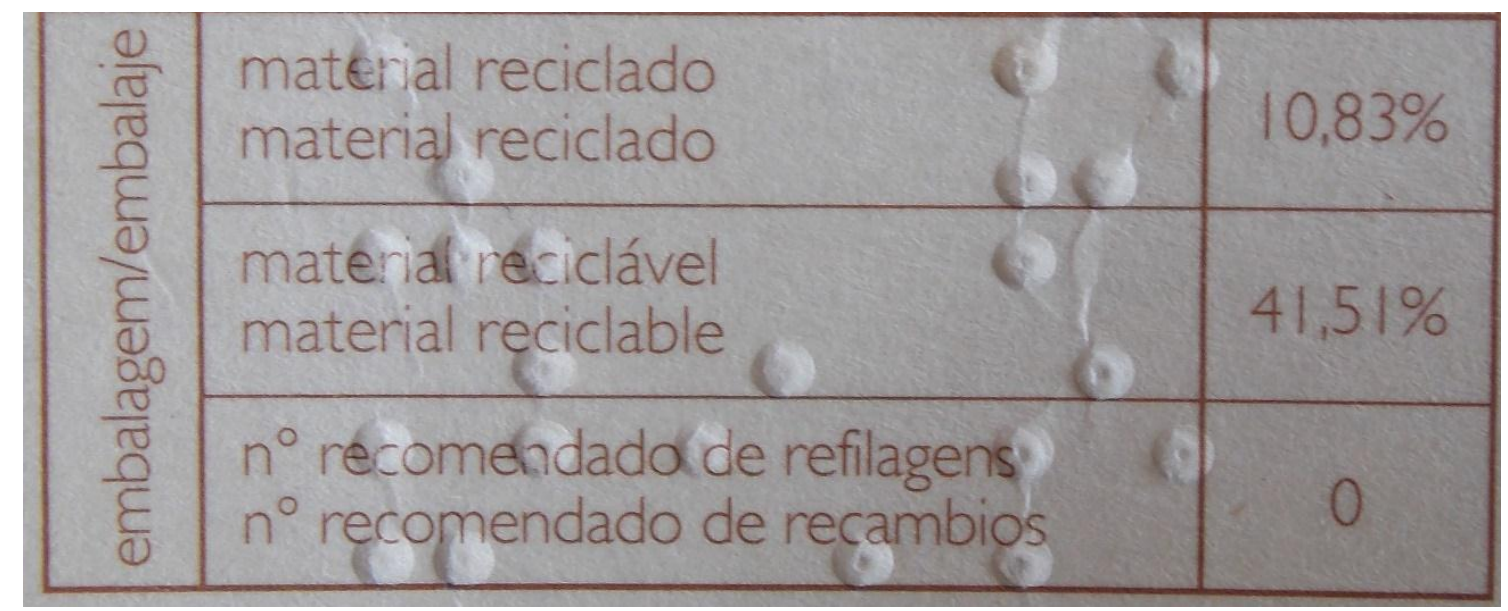

Figura 10: Informações de Embalagem na tabela ambiental do produto óleo corporal Natura.

As informações de embalagem estão relacionadas diretamente com a geração de resíduos sólidos. De acordo com a Natura, o refil tem, em média, $54 \%$ menos massa do que a embalagem padrão, reduzindo, desta maneira, a geração de cerca de 2,2 mil toneladas de resíduos pós-consumo no ano. Infelizmente, o que se observa em relação aos critérios de embalagem é a dificuldade do consumidor de entender as informações disponibilizadas. Não há, por exemplo, o entendimento da diferença entre material reciclável e o reciclado que compõe a embalagem.

Em relação à formulação do produto, observam-se outros três critérios para a tabela ambiental: uso de matéria-prima certificada; matéria-prima de origem vegetal; e, matéria-prima de origem vegetal natural. 


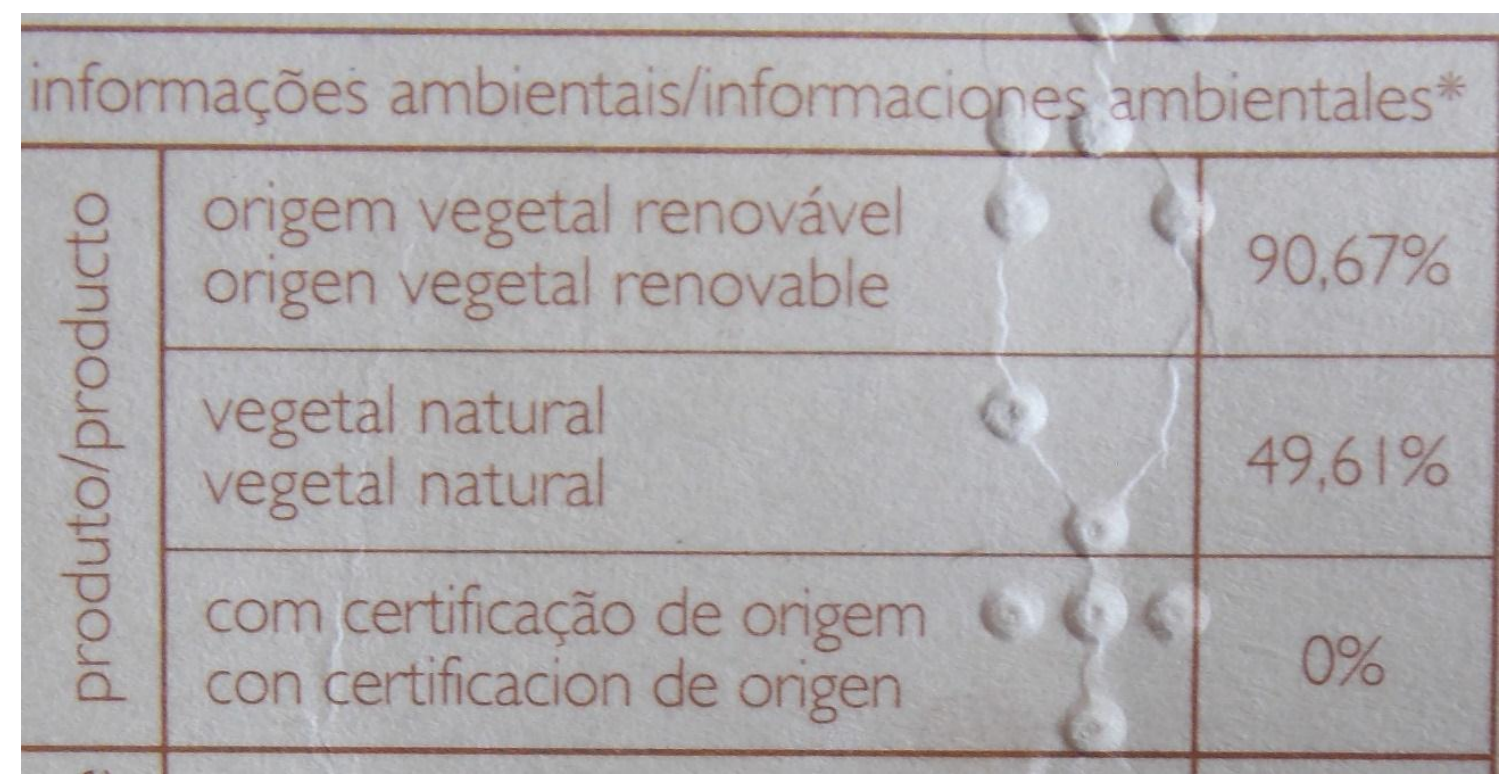

Figura 11: Informações de Formulação na tabela ambiental do produto óleo corporal da Natura.

Para matérias-primas com certificação de origem a empresa utiliza-se, não apenas, mas principalmente, da certificação de orgânicos. A ideia é garantir que toda cadeia produtiva seja sustentável, evitando-se problemas de trabalho escravo ou infantil e degradação ambiental no cultivo de insumos vegetais. No caso de matéria-prima de origem vegetal, considera-se também a porcentagem base vegetal em insumos sintéticos. O cálculo é realizado no peso seco, já que em peso úmido a quantidade de água poderia influenciar no resultado. Matériasprimas de origem vegetal natural não apresentam matéria-prima sintética em sua composição, o insumo não passa por qualquer alteração molecular, sendo utilizado em sua forma natural.

As informações relacionadas à formulação são ainda mais difíceis para o consumidor entender os benefícios. Matérias-primas de fonte vegetal e mineral, e o significado do vegetal natural, podem causar confusão, pois não há um entendimento por parte do consumidor dos processos pelos quais uma matériaprima pode passar e na visão do leigo todos esses insumos seriam naturais.

$O$ que se observa em relação a tabela ambiental divulgada na rotulagem é que o consumidor desconhece as informações disponibilizadas. A falta de mensagens rápidas, como símbolos e selos, nos rótulos dos produtos da empresa ainda mais a associação dos consumidores à mensagem de sustentabilidade que a Natura deseja passar. 
A estratégia de comunicação deve ser muito bem estabelecida para conscientizar o consumidor sobre os benefícios ambientais e de sustentabilidade de um determinado produto, o que não ocorreu no processo da Natura. Há ainda, por falta de conhecimento do processo, alguns casos em que a própria mídia desconstrói a proposta da empresa, dificultando ainda mais uma conscientização do consumidor.

A comunicação ambiental ainda apresenta fraquezas. A maioria dos consumidores não consegue identificar um produto "verde" ou sustentável, isso demonstra que grande parte dos rótulos ambientais não estão conseguindo passar a mensagem que deseja ou convencer os consumidores. Muitos produtos de consumo utilizam símbolos para transmitir a informação ambiental, porém, de acordo com pesquisas realizadas, esses nem sempre são entendidos pelos consumidores, perdendo sua efetividade na comunicação (BORIN et al, 2011).

De maneira geral, as pessoas entendem as limitações dos rótulos ambientais e de sustentabilidade, dando votos de confiança às informações fornecidas. Porém, informações incorretas podem acarretar desconfiança e equiparar um produto sustentável a outro comum (CHEN, et al, 2014).

Para tentar resolver o problema de comunicação com o consumidor e seu entendimento, a Natura desenvolveu seis elementos de comunicação, com mensagens rápidas, para seus produtos: 1) vegetal natural; 2) teste em animais; 3) embalagem sustentável; 4) carbono neutro; 5) impacto social positivo; 6) sistema B Corp (tripé da sustentabilidade incorporado ao negócio).

O impacto social positivo está diretamente relacionado ao pilar social e diz respeito à geração de renda, com a venda dos produtos Natura (consultoras). $\mathrm{O}$ sistema B Corp foi descrito no início deste estudo, nas características da empresa.

Nesse meio de comunicação criado, a empresa destaca (1) a origem vegetal de seus produtos, sendo essas de fontes renováveis, gerando menor impacto ambiental. No caso dos testes em animais (2) há dez anos a Natura já tem como política não realizar testes em animais no desenvolvimento de seus produtos, utilizando metodologias alternativas, não garantindo, porém, que esse tipo de teste não seja feito em toda cadeia (fornecedores de matérias-primas), já que por questões regulatórias muitos insumos devem ser testados para gerar 
dados. A Natura reforça que estimula a redução de testes em animais para seus fornecedores.

No que tange as embalagens (3) a ideia é demonstrar ao consumidor que o uso do refil é benéfico e reduz a geração de resíduos pós-consumo. Além disto, tem um papel importante na conscientização do consumidor no descarte adequado da embalagem, conforme identificação por tipo de material, garantindo o retorno da embalagem para os processos de reciclagem.

O consumidor ainda tem dificuldade de perceber e identificar um produto sustentável. É o caso, por exemplo, dos produtos em refil, que só são adquiridos pelo consumidor por ter um preço mais baixo do que o produto em embalagem regular. Isto é percebido pela empresa quando ocorrem ações específicas de venda e o produto regular é comercializado com o mesmo preço do refil e o maior volume de compra passa a ser do regular. Isto demonstra que a escolha ainda é determinada pelo preço e não por um apelo de sustentabilidade.

No cosmético o apelo ambiental tende a perder espaço para a qualidade. A escolha do consumidor está atrelada ao reconhecimento da marca como sendo um produto de qualidade e não como sendo ambientalmente melhor.

Em pesquisa realizada em países europeus, em 2013, foi observado que ao hierarquizar os critérios para decisão de compra, as questões ambientais aparecem em terceiro lugar, quando bem colocadas, variando de posição conforme o país, o nível de educação e a renda dos entrevistados. De modo geral, as decisões de compra são baseadas, em primeiro lugar pela qualidade do produto, seguido do preço, funcionalidade, questões ambientais e moda. $\mathrm{Na}$ Bélgica, onde nos anos 80 houve um programa para o consumo sustentável e rotulagem ambiental, as questões ambientais apareceram como um dos critérios principais para a compra, ao contrário da Polônia, em que a população teve mais acesso às informações de impacto ao meio ambiente após a entrada na Comunidade Europeia (ANDRYKIEWICZ, 2014).

Em carbono neutro (4), desde 2007 a empresa neutraliza suas emissões, em todo ciclo de vida do produto, desde a extração das matérias-primas até o descarte. Infelizmente, ainda não é possível determinar a pegada de carbono de todos os produtos da empresa, pois não há uma metodologia definida para medição, já que há partes do processo produtivo que são terceirizados ou podem 
ser terceirizados no futuro, dificultando a identificação dos impactos no processo produtivo desses terceiros.

A ACV na empresa é feita para o produto, embalagem e ambiente corporativo. No caso do produto e embalagem, utilizam-se os dados dos fornecedores, da formulação e o design do produto, permitindo a melhor identificação do impacto.

Os dados utilizados para a avaliação do ciclo de vida são advindos de banco de dados internacionais e modelos próprios construídos. É essencial que a empresa tenha a participação de seus fornecedores de matéria-prima, já que muitos dados são originados por eles. A Natura certifica e premia os fornecedores estimulando, assim que toda cadeia gere dados em ciclo de vida de produtos. Observa-se que há uma forte interação com os fornecedores da Natura, para se obter os dados necessários para a ACV, porém, ainda há dificuldades em se conseguir alguns dados com determinados fornecedores.

A ACV não é comunicada diretamente para o consumidor, tendo em vista que estas informações são bastante específicas e do processo produtivo como um todo. É nesse sentido que a rotulagem ambiental gerada através da Declaração Ambiental de Produto pode ser uma forma de comunicar os impactos mapeados com a ACV.

Dada a impossibilidade de o consumidor checar as características ambientais de um determinado produto, a credibilidade é determinada pela veracidade e confiabilidade da informação fornecida pelas empresas e verificada por uma parte neutra. Neste processo é importante a transparência na verificação. Cabe ao operador do sistema e os órgãos responsáveis pela política, garantirem que as informações publicadas estejam corretas (HUNSAGER et al, 2014).

Ainda na visão do entrevistado, a rotulagem tipo III terá uma forte integração com políticas ambientais já existentes. A Política Nacional de Mudanças Climáticas pode ser um forte estimulador da adoção da rotulagem, já que pode ter influência nas questões de selos de identificação e, consequentemente, na mudança nos padrões de escolha do consumidor. A Política Nacional de Resíduos Sólidos traz mais benefícios para o processo produtivo e produtividade do que para o consumidor, contribuindo na adoção da 
metodologia de ACV e na análise do ciclo de carbono, ainda pouco discutido no país.

Especificamente sobre a política do Programa de Rotulagem Tipo III DAP do INMETRO, a empresa informou não ter finalizado a análise da norma e, por esta razão, não conseguiu opinar sobre a aplicabilidade desta em seus produtos e nem a relação com sua rotulagem ambiental atual. Sobre aplicação da Lei francesa de rotulagem, a Natura informou que as operações na Europa são próprias e não dependem de ações no Brasil.

\subsection{O caso da entidade PROCOBRE}

A DAP setorial elaborada pela Associação PROCOBRE - Instituto Brasileiro do Cobre - foi uma iniciativa voluntária, para tubos de cobre, colocada em prática em 2014. O projeto teve sua execução em um ano e para a elaboração da DAP foi contratada uma consultoria internacional especializada.

De acordo com o entrevistado, a entidade não avaliou, até o momento, o Programa de rotulagem tipo III do INMETRO, e, por esta razão, não soube fazer uma análise crítica sobre tal.

Em relação ao programa do PROCOBRE e a busca das informações, duas foram as fontes para a aquisição de informações de ACV para a elaboração da DAP: empresas associadas que já tinham ACV para seus produtos e banco de dados internacionais.

As informações de ACV conseguidas através de banco de dados internacionais foram aqueles referentes à principal matéria-prima do tubo de cobre (cátodo). Para este caso, já existiam estudos internacionais, permitindo à consultoria a captação dos dados e a adaptação destes para o Brasil.

Para a fabricação do tubo e outras matérias-primas foram utilizadas informações geradas por duas empresas associadas ao PROCOBRE, que respondem por $90 \%$ do mercado de tubos de cobre, e já haviam realizado ACV para os seus produtos. Neste caso, a consultoria recebeu os dados de maneira confidencial, consolidou-os e utilizou as informações na DAP. Isto permitiu a elaboração de uma declaração setorial, sem abertura de dados confidenciais.

O limite para a análise foi do "berço ao portão", ou seja, da entrada da matéria-prima no processo produtivo, até a saída do produto final da fábrica. 
Portanto, não foram levados em consideração os impactos relacionados à fabricação da matéria-prima ou do consumo e descarte pós-consumo.

O processo completo de elaboração da DAP e verificação dos dados por um organismo certificador custou para a entidade algo na ordem de US\$50 a 60 mil ao ano. A entidade não soube informar se a Declaração está registrada em algum programa ou não. A DAP foi disponibilizada para os associados e encontra-se disponível na página eletrônica do PROCOBRE.

De acordo com o responsável pelo projeto na entidade, a DAP setorial, neste caso, somente foi possível por existirem empresas que já possuíam dados, por já haver informações internacionais sobre o produto e por se tratar de um setor concentrado. No caso do setor de cosméticos, e outros produtos de consumo geral, uma DAP setorial torna-se mais difícil, já que são setores pulverizados, com diversas formulações e diversos produtos. Uma DAP simplificada poderia gerar confusão no consumidor e, talvez, não seria capaz de refletir os reais impactos ambientais que estão sendo causados pelo processo produtivo e consumo.

Quando se trata de bens de consumo, há ainda outra questão. A dificuldade de entender que não necessariamente a rotulagem ambiental permite a comparação direta entre produtos. Esta rotulagem, baseada na DAP, permite que se conheça os impactos causados ao meio ambiente com a produção, mas isso não quer dizer, necessariamente, que um produto é melhor que o outro.

Há ainda a questão do custo para elaboração e verificação da DAP. Um valor de US\$50 mil torna-se proibitivo para pequenas e médias empresas. Um programa estruturado no Brasil deve considerar que grande parte das empresas nacionais estão classificadas nesses portes e, portanto, o Programa deve ser inclusivo, para tornar-se uma política de sustentabilidade de fato.

Para o entrevistado, a DAP tem uma relação direta com a política nacional de mudanças climáticas, tendo em vista que na ACV torna-se possível a identificação dos impactos de emissão do processo produtivo.

A entrevista realizada com a empresa Natura S.A. mostrou o quanto a rotulagem ambiental pode contribuir para a identificação dos impactos no processo produtivo, mas o quanto o consumidor ainda não está preparado para 
entender e absorver as informações ambientais ou de sustentabilidade disponibilizadas nos rótulos dos produtos.

Já a entrevista realizada com o Instituto PROCOBRE demonstrou as dificuldades que podem ser enfrentadas pelas empresas ou setores que optarem por implementar a DAP. A adoção da DAP pode ser um processo de alto custo e com grandes dificuldades como a execução da ACV e a captação de informações necessárias para isso.

É preciso que a política proposta pelo INMETRO tenha tempo de amadurecimento para que seja integrada com demais políticas ambientais e de sustentabilidade e para que possa ser implementada pelas empresas nacionais. Caso tenha-se demanda para a implementação da rotulagem tipo III em produtos de consumo um trabalho de educação com o consumidor será essencial. 


\section{CONCLUSÃO}

A Política elaborada e publicada pelo INMETRO ainda não pode ser totalmente implementada dada as necessidades de estruturação do operador do sistema, um sistema de registro das DAP e a iniciativa das empresas em elaborar uma RCP.

Esse Programa é bastante recente o que dificulta a análise de sua implementação pelas empresas instaladas no Brasil. O que é possível dizer é que, de maneira geral, o Programa Brasileiro de DAP e rotulagem tipo III segue modelos mundiais permitindo, em algum momento, a entrada do Brasil em sistemas globais. Além disto, torna-se mais fácil o reconhecimento mútuo do programa do Brasil com os dos demais países. Isso é um ponto forte do sistema brasileiro, pois pode garantir o comércio exterior das empresas nacionais.

O sistema brasileiro apresenta diversos pontos fortes, mas algumas fraquezas e ameaças merecem atenção, conforme apontados na análise SWOT. A preparação de profissionais capacitados para elaborar e analisar as Regras de Categorias de Produtos e as Declarações Ambientais de Produtos é essencial tanto para as empresas que gerarão a demanda de início do processo, como para o governo e os Organismos Certificadores que avaliarão as informações disponibilizadas.

É preciso que o governo brasileiro avance nas questões relacionadas ao banco de dados nacionais em ciclo de vida para que se tenham os dados necessários para o inventário. Isto pode tornar as informações mais acessíveis e, consequentemente, permitir que mais empresas participem do programa.

Talvez, com a existência de um banco de dados nacional o setor privado torne-se menos resistente à implementação da ACV em seus processos produtivos. A disponibilidade de dados pode contribuir para a redução do custo de se realizar uma ACV, o que permitiria o acesso de empresas nacionais de médio porte.

Como uma das ameaças identificadas na análise SWOT foi a possibilidade de desconhecimento do Programa DAP por parte das empresas no Brasil. A elaboração de guias e manuais capazes de orientá-las pode contribuir para a implementação do programa por um número maior de empresas e setores. Outro ponto que pode auxiliar a minimizar essa ameaça é a divulgação 
do Programa. Cabe ao INMETRO realizar eventos e rodadas de apresentação do sistema brasileiro de DAP, despertando as empresas para essa política que pode contribuir com a produção e o consumo sustentáveis.

O Brasil já possui algumas políticas de sustentabilidade e meio ambiente possíveis de serem integradas ao Programa de DAP do INMETRO e estimular a adoção deste. Se faz necessário nesse caso a ação governamental de análise para a elaboração de outros instrumentos capazes de integrar todas as políticas.

Fica claro que as empresas que participam do mercado externo tendem a dar início ao uso da rotulagem tipo III, tendo em vista as exigências de outros países. Produtos que são comercializados apenas internamente somente utilizarão o rótulo se observarem uma forte tendência de mercado (o que ainda não é possível notar no consumidor - jurídico ou físico) ou se for obrigatório.

No que tange o setor de cosméticos, ainda não houve a adoção da rotulagem por parte das empresas, apesar de já haver iniciativas em rotulagem ambiental certificada. Mais uma vez, falta às empresas entender a política do INMETRO (ainda muito recente) e verificar o interesse do consumidor em ter estas informações. Muitas iniciativas já existem nesse setor no que se refere a políticas de sustentabilidade e meio ambiente, facilitando a integração com o Programa de DAP. Esta integração pode ocorrer a partir da relação da DAP com as demais políticas ambientais e de sustentabilidade ou com o amadurecimento do Programa.

É preciso ainda que o programa de DAP seja visto como uma política além da prestação de informação e passe a ser vista como uma forma de identificar impactos e alterar o processo produtivo, tornando-o mais sustentável. 


\section{REFERÊNCIAS BIBLIOGRÁFICAS}

ABIHPEC, ASSOCIAÇÃO BRASILEIRA DAS INDÚSTRIAS DE HIGIENE PESSOAL, P. E C. PANORAMA DO SETOR Higiene Pessoal, Perfumaria e Cosméticos, 2015. Disponível em: <https://www.abihpec.org.br/wpcontent/uploads/2015/04/2015-PANORAMA-DO-SETOR-PORTUGUÊS31mar2015.pdf>

AFNOR. Grenelle Law. Disponível em: <http://www.afnor.org/profils/situation/particuliers/grenelle-de-l-environnementles-conditions-d-affichage-de-l-impact-environnemental-des-produits-sontdefinies>. Acesso em: 1 jul. 2016a.

AFNOR. Ecolabel. Disponível em: <http://www.ecolabels.fr/fr/espaceprofessionnels/industriels-prestataires-les-ecolabels/les-modalites-de-lacertification>. Acesso em: 2 jul. 2016b.

AMACHER, G. S.; KOSKELA, E.; OLLIKAINEN, M. Environmental quality competition and eco-labeling. Journal of Environmental Economics and Management, v. 47, n. 2, p. 284-306, 2004.

ANDRYKIEWICZ, A. INTEGRATED PRODUCT POLICY IN THE PROCESS OF DEVELOPING THE pro-environmental CONSUMER ATTITUDE IN THE GIVEN EUROPEAN UNION COUNTRIES . v. 13, n. 1, 2014.

ATSM. Environment Product Declaration Program. Disponível em: <http://www.astm.org/CERTIFICATION/filtrexx40.cgi?P+PROG+7+cert_detail.frm>. Acesso em: 20 jun. 2016.

AUSTRUMA, S. Change of values in the consumer society. SHS Web of Conferences, v. 2, p. 00004, 2012.

BALDO, G. L. et al. The use of LCA to develop eco-label criteria for hard floor coverings on behalf of the european flower. The International Journal of Life 
Cycle Assessment, v. 7, n. 5, p. 269-275, 2002.

BARBOSA JÚNIOR, A. F. et al. Conceitos e aplicações de Análise do Ciclo Vida (ACV) no Brasil. Revista Gerenciais, São Paulo, v. 7, n. 1, p. 39-44, 2008., p. 39-44, 2008.

BARRETO, A. P. L. et al. Ciclo de Vida de Produtos: Certificação e Rotulagem Ambiental. XXVII Encontro Nacional de Engenharia de Produção, p. 9, 2007.

BINAGHI, L.; DEL BORGHI, M.; GALLO, M. The Application of the Environmental Product Declaration to Waste Disposal in a Sanitary Landfill - Four Case Studies (10 pp). The International Journal of Life Cycle Assessment, v. 12, n. 1, p. 40-49, 2007.

BOGESKÄR, M. et al. Evaluation of Environmental Product Declaration Schemes. Journal of Environmental Engineering and Science, v. 1, n. 6, p. $119,2002$.

BORIN, N.; CERF, D. C.; KRISHNAN, R. Consumer effects of environmental impact in product labeling. Journal of Consumer Marketing, v. 28, n. 1, p. 7686, 2011.

BORLOO, J. Grenelle 2 law. p. 6-17, 2010.

BOVESPA. Índice de Sustentabilidade Empresarial. Disponível em: $<$ http://www.bmfbovespa.com.br/pt_br/produtos/indices/indices-desustentabilidade/indice-de-sustentabilidade-empresarial-ise-1.htm>. Acesso em: 1 maio. 2015.

BOVESPA. Índice de Sustentabilidade Empresarial. Disponível em: <file://C:/Users/Veronica/Downloads/Carteira-ISE-2016.pdf>. Acesso em: 10 jun. 2016. 
BRAMMER, Stephen; WALKER, Helen. Sustainable procurement in the public sector: an international comparative study. International Journal of Operations \& Production Management, vol. 31, 2011. p. 452 - 476.

BRASIL. Política Nacional sobre Mudança do Clima. Lei 12.187, de 29 de dezembro de 2009.

CALABRO, G. THE EU-POLICY OF PROMOTING GREEN PURCHASES : THE ROLE OF ECOLOGICAL LABELLING. Forum Ware International, v. 1, p. 1-7, 2007.

CECI-RENAUD, N.; KHAMSING, W. T. Consumers faced with environmental labelling. General Directorate for Sustainable Development - Department for the Economy, Evaluation and Integration of Sustainable Development, , 2012.

CHARTER, M. et al. Integrated Product Policy and Eco-Product Development. Sustainable Solutions, p. 98-116, 2001.

CHEN, X.; ALFNES, F.; RICKERTSEN, K. Consumer Preferences, Ecolabels, and the Effects of Negative Environmental Information. v. 18, n. 3, p. 1-31, 2014.

COLTRO, L. Avaliação do ciclo de vida como instrumento de gestão. [s.l: s.n.].

COSTA, R. H. Apontamentos sobre a Tributação Ambiental no Brasil. Lusíada. Direito e Ambiente, v. 2/3, p. 329 - 348, 2011.

DEL BORGHI, A. LCA and communication: Environmental Product Declaration. International Journal of Life Cycle Assessment, v. 18, n. 2, p. 293-295, 2013.

ENI, F.; MATTEI, E. Use of Ecolabels in Promoting Exports from Developing Countries to Developed Countries: Lessons from the Indian Leather Footwear Industry. Social Science Research, n. I, 2005. 
ENVIRONMENTAL PROTECTION AGENCY, U. S. Environmental Labeling Issues, Policies, and Practices Worldwide. [s.I: s.n.].

EUROBAROMETER. Attitudes of europeans towards building the single market for green products. TNS Political \& Social. 2013.

EUROPEAN COMISSION. On the State of Implementation of Integrated Product Policy. [s.l: s.n.].

EUROPEIA, U. Regulation (EC) $n^{\circ}$ 66/2010, 2010.

FET, A. M.; SKAAR, C.; MICHELSEN, O. Product category rules and environmental product declarations as tools to promote sustainable products: Experiences from a case study of furniture production. Clean Technologies and Environmental Policy, v. 11, n. 2, p. 201-207, 2009.

FINKBEINER, M. Carbon footprinting - opportunities and threats. International Journal of Life Cycle Assessment, v. 14, p. 91-94, 2009.

FINKBEINER, M. Product environmental footprint - Breakthrough or breakdown for policy implementation of life cycle assessment? International Journal of Life Cycle Assessment, v. 19, n. 2, p. 266-271, 2014.

GALLASTEGUI, I. G. THE USE OF ECO-LABELS: A REVIEW OF THE LITERATURE. European Environment, v. 12, p. 316-331, 2002.

GROUP, C. Environment Product Declarations. Disponível em: $<w w w . c s a r e g i s t r i e s . c a / e p d / a b o u t \_e p d \_p c r s \_e . c f m>$.

GRUÈRE, G. A Characterisation of Environmental Labelling and Information Schemes. n. 62, p. 47, 2013.

GUIMARÃES, P. C. V.; DEMAJOROVIC, J.; OLIVEIRA, G. DE. Estratégias empresariais e instrumentos econômicos de gestão ambiental. Revista de 
Administração de Empresas, v. 35, n. 5, p. 72-82, 1995.

HOE, V. M. H. Os desafios da Gestão Governamental na implementação das compras públicas no âmbito do Plano Nacional de Produção e Consumo Sustentáveis. [s.I.] Escola Paulista de Direito, 2014.

HORNE, R. E. Limits to labels: The role of eco-labels in the assessment of product sustainability and routes to sustainable consumption. International Journal of Consumer Studies, v. 33, n. 2, p. 175-182, 2009.

HUNKELER, D. Societal LCA Methodology and Case Study. The International Journal of Life Cycle Assessment, v. 11, n. 6, p. 371-382, 2006.

HUNSAGER, E. A.; BACH, M.; BREUER, L. An institutional analysis of EPD programs and a global PCR registry. International Journal of Life Cycle Assessment, p. 1-10, 2014.

IBICT, I. B. DE I. EM C. E T. DESENVOLVIMENTO SUSTENTÁVEL E AVALIAÇÃO DO CICLO DE VIDABrasíliaCNI, , 2014.

INMETRO, Q. E. T.-. Ministério do desenvolvimento, indústria e comércio exterior, 2015.

IPEA. O uso do poder de compra para a melhoria do meio ambienteComunicado IPEA: Eixos do Desenvolvimento Brasileiro. [s.l: s.n.].

ISO. NBR ISO 14025:2015 - Rótulos e declarações ambientais - Declarações ambientais de Tipo III - Princípios e procedimentos, 2015.

JEMAI. Base Document: EcoLeaf/Carbon Footprint Communication Program. [s.I: s.n.]. Disponível em: <http://www.ecoleaf-jemai.jp/eng/data/JG01-02.pdf>.

JEMAI, J. E. M. A. FOR I. Eco Leaf - History. Disponível em: 
$<$ http://www.ecoleaf-jemai.jp/eng/data/History.pdf>.

JURAS, I. DA A. G. M.; ARAÚJO, S. M. V. G. DE. A responsabilidade compartilhada pelo ciclo de vida do produto. In: JARDIM, A.; YOSHIDA, C.; MACHADO FILHO, J. V. (Eds.). . Política Nacional, Gestão e Gerenciamento de Resíduos Sólidos. Barueri: Manole, 2012. p. 57-77.

KEITI, K. E. I. \& T. I. Ecolabelling. Disponível em: $<w w w . k e i t i . r e . k r / e n / s u b P a g e . d o ? m e n u l d=2080404000$.

LI, L.; GEISER, K. Environmentally responsible public procurement (ERPP) and its implications for integrated product policy (IPP). Journal of Cleaner Production, v. 13, n. 7, p. 705-715, 2005.

MACERON FILHO, O; ARAÚJO, E. A. S.; QUINTAIROS, P. C. R. A análise SWOT e sua relevância para o planejamento estratégico. III Congresso Internacional de Ciência, Tecnologia e Desenvolvimento. Universidade de Taubaté, outubro/2014.

Disponível em: http://www.unitau.br/files/arquivos/category 154/MCH0396 1427385441.pdf, acessado em 21/01/2016.

MARKET ANALISYS. Green Washing no Brasil: um estudo sobre os apelos ambientais nos rótulos dos produtos. 2014. Disponível em: http://marketanalysis.com.br/wp-content/uploads/2014/07/Greenwashing-inBrazil.pdf, acessado em, 05/04/2015.

MINISTÉRIO do PLANEJAMENTO, ORÇAMENTO E GESTÃo. Painel de Compras do Governo Federal. Estatísticas de 2015. Disponível em: http://paineldecompras.planejamento.gov.br/QvAJAXZfc/opendoc.htm?docume nt=Painel\%20de\%20Compras.qvw\&host=QVS\%40winuep82|primh\&anonymous=true, acessado em 05/03/2016.

MINISTRY OF ENVIRONMENT AND FOREST, M. ECO Mark Labelling. Disponível em: <http://www.moef.nic.in/public-information/schemes-and- 
programmes>. Acesso em: 30 jun. 2015.

MINISTRY OF ENVIRONMENT AND FOREST, M. G.S.R. 768(E)Índia, 1992.

MINKOV, N. et al. Type III Environmental Declaration Programmes and harmonization of product category rules: status quo and practical challenges. Journal of Cleaner Production, v. 94, p. 235-246, 2015.

MOURA, A. M. M. DE. O MECANISMO DE ROTULAGEM AMBIENTAL: Perspectivas de aplicação no Brasil. IPEA, Boletim regional, urbano e ambiental, v. 07, n. jan-jun, p. 11-21, 2013.

NAIME, R. Programas Eco Mark no Japão e na Índia. Disponível em: $<$ https://www.ecodebate.com.br/2013/09/24/programas-eco-mark-no-japao-ena-india-artigo-de-roberto-naime/>. Acesso em: 5 jul. 2015.

NAKAHIRA, É.; MEDEIROS, G. A. DE. Rotulagem Ambiental : O Caso Do Setor Cosmético. Mais Ou Menos, p. 544-563, 2009.

NATRUE. Organic Cosmetics. Disponível em: <http://www.ioas.org/services/organic-cosmetics/>. Acesso em: 1 maio. 2016.

NATURA. Natura Empresa B Corp. Disponível em: <http://www.natura.com.br/a-natura/sustentabilidade/natura-b-corp>. Acesso em: 8 maio. 2016.

NATURA. Sustentabilidade Natura. Disponível em: <http://www.natura.com.br/e/sustentabilidade>. Acesso em: 2 jun. 2016.

NATURA. Relatório Anual Natura S/A. Disponível em: <http://www.natura.com.br/relatorio-anual/2015>. Acesso em: 9 jul. 2016.

NORRIS, G. et al. ACV - Conceitos para o desenvolvimento industrial na América Latina. In: CALDEIRA-PIRES, A.; SOUZA-PAULA, M. C. DE; VILLAS BÔAS, R. 
C. (Eds.). . Avaliação do Ciclo de Vida - A ISO 14040 na América Latina. Brasília: ABIPTI, 2005. p. 330.

PNUMA, P. DAS N. U. PARA O M. A. A Produção mais Limpa e o Consumo Sustentável na América Latina e Caribe. [s.l: s.n.]. Disponível em: <http://www.cqgp.sp.gov.br/gt_licitacoes/publicacoes/AProducaoMaisLimpaeoC onsumoSustentavelNaALeC.pdf>.

RASHID, N.; JUSOFF, K.; KASSIM, K. Eco-Labeling Perspectives amongst Malaysian Consumers. Canadian Social Science, v. 5, n. 2, p. 1-10, 2009.

REBITZER, G. et al. Life cycle assessment Part 1: Framework, goal and scope definition, inventory analysis, and applications. Environment International, v. 30, n. 5, p. 701-720, 2004.

SALAZAR, E. Life Cycle Assessment of Newsprint Distribution at an Integrated Mill, 2004.

SANTOS, C. G. Declaraciones Ambientales de Producto: instrumento para la mejora de productos. [s.I.] Universitat Autònoma de Barcelona, 2012.

SCHAU, E. M.; FET, A. M. LCA studies of food products as background for environmental product declarations. The International Journal of Life Cycle Assessment, v. 13, n. 3, p. 255-264, 2008.

SCHENCK, R. The outlook and opportunity for Type III environmental product declarations in the United States of America. ... for Environmental Research and Education: A Policy ..., 2009.

SECRETARIA DO PLANEJAMENTO, CIÊNCIA E TECNOLOGIA. Metodologia de avaliação de políticas públicas: uma abordagem preliminar. Salvador, 1999. $44 p$.

Disponível em: http://www.gestaosocial.org.br/conteudo/parceiros/fapesb/referencia/textometodologia-de-avaliacao-seplantec.pdf, acessado em 21/01/2016. 
SHARMA, V. K.; KURANI, Y. S. State of environmental product declarations (EPDs) in India. The International Journal of Life Cycle Assessment, v. 9, n. 1, p. 69-69, 2004.

SILVA, A. B. da. A tributação extrafiscal sobre a taxa de licenciamento ambiental: um estudo de caso de uma empresa de beneficiamento de resíduos sólidos no estado do Amazonas. Dissertação de Mestrado. Manaus: Universidade do Estado do Amazonas, 2014. p. 30.

SILVA, G. A. DA. Avaliação do ciclo de vida (ACV)São PauloAssociação Brasileira de Ciclo de Vida, , 2013. Disponível em: $<$ http://www.ecoinvent.org/fileadmin/documents/en/presentation_papers/Presen tation_2013/Introducao_a_ACV.pdf>

SUBRAMANIAN, V. et al. Comparing product category rules from different programs: Learned outcomes towards global alignment. International Journal of Life Cycle Assessment, v. 17, n. 7, p. 892-903, 2012.

SYSTEM, T. I. E. General Programme Instructions for International EPD System. [s.l: s.n.]. Disponível em: <www.environdec.com>.

TAMANAHA, R. T. Risco ambiental, economia e tributação: o emprego das normas tributárias indutoras em prol da sustentabilidade, 2013.

TRAVASSOS, P. F. S.; VIEIRA, F. O. Aplicação da análise SWOT, na preparação do processo de avaliação institucional interna (auto-avaliação) realizada pela IES. Revista Eletrônica de Administração, vol. 10, nº 02, edição 19, jul - dez/2011. p. 1 - 14.

TRINDADE, P. 7.6. Rotulagem Ambiental, [s.d.]. 
ANEXO I 


\section{ROTEIRO DE ENTREVISTA PARA EMPRESAS}

1) Como a empresa está vendo a publicação do regulamento do INMETRO?

2) A empresa realiza ACV? Faz muito tempo? A empresa possui banco de dados próprios?

3) É possível o compartilhamento de dados? Como a empresa entende que se encontram os bancos de dados brasileiros em ACV hoje?

4) Como ocorreu o processo de rotulagem do produto?

5) O consumidor entende a rotulagem? Esse tipo de informação ambiental, agrega valor ao produto para o consumidor? A escolha do consumidor é feita pelas informações ambientais?

6) Já avaliaram a situação da DAP e rotulagem em outros lugares do mundo?

7) Políticas de estímulo e incentivo, auxiliaria na implementação da rotulagem tipo III? Com quais políticas acredita que a rotulagem tipo III pode ser integrada? 


\section{ROTEIRO DE ENTREVISTA PARA REPRESENTANTES DA INDÚSTRIA}

8) Como a entidade/empresa está vendo a publicação do regulamento do INMETRO?

9) Quais os possíveis impactos para a indústria com a existência de uma política para declaração ambiental e rotulagem ambiental? O problema seria a DAP e a rotulagem ou a questão da ACV?

10) Há impacto diferente para as pequenas empresas? Como a entidade vê a adequação destas empresas ao regulamento?

11) Não seria esta política positiva para empresas que exportam? A entidade entende que pode haver impactos na importação de produtos?

12) A entidade acredita que, em se tratando de uma política voluntária, as empresas irão aderir aos requisitos?

13) Já avaliaram a situação da DAP e rotulagem em outros lugares do mundo?

14) Se houvessem políticas de estímulo e incentivo, isto auxiliaria na adequação das indústrias? A entidade já tem alguma sugestão das políticas que poderiam ser usadas?

15) Quais as vantagens para a indústria se elas aderirem a esta política? 